\title{
Carbon dioxide emissions from Tucuruí reservoir (Amazon biome): New findings based on three-dimensional ecological model simulations
}

\author{
Marcelo Pedroso Curtarelli a,*, Igor Ogashawara ${ }^{\mathrm{b}}$, Carlos Alberto Sampaio de Araújo a , \\ João Antônio Lorenzzetti ${ }^{\mathrm{a}}$, Joaquim Antônio Dionísio Leão ${ }^{\mathrm{a}}$, Enner Alcântara ${ }^{\mathrm{c}}$, José Luiz Stech ${ }^{\mathrm{a}}$ \\ a Remote Sensing Division, National Institute for Space Research, 12227010 São José dos Campos, São Paulo, Brazil \\ ${ }^{\mathrm{b}}$ Department of Earth Sciences, Indiana University-Purdue University Indianapolis, Indianapolis, IN, USA \\ c Department of Cartography, São Paulo State University, 19060900 Presidente Prudente, São Paulo, Brazil
}

\section{H I G H L I G H T S}

- We simulated the diffusive dioxide carbon flux from an Amazonian reservoir.

- We assessed the spatio-temporal dynamics of carbon flux for two different seasons.

- The surface averaged flux showed no significant difference between the seasons.

- The flux showed to be more heterogeneous during the wet than during the dry season.

- The total $\mathrm{CO}_{2}$ emitted by the reservoir was estimated to be $1.1 \mathrm{Tg} C$ year -1 .

\section{A R T I C L E I N F O}

\section{Article history:}

Received 27 August 2015

Received in revised form 31 January 2016

Accepted 1 February 2016

Available online 22 February 2016

Editor: D. Barcelo

\section{Keywords:}

Numerical modeling

Greenhouse gases emission

Carbon dioxide

Hydroelectric reservoirs

Amazon biome

\section{G R A P H I C A L A B S T R A C T}

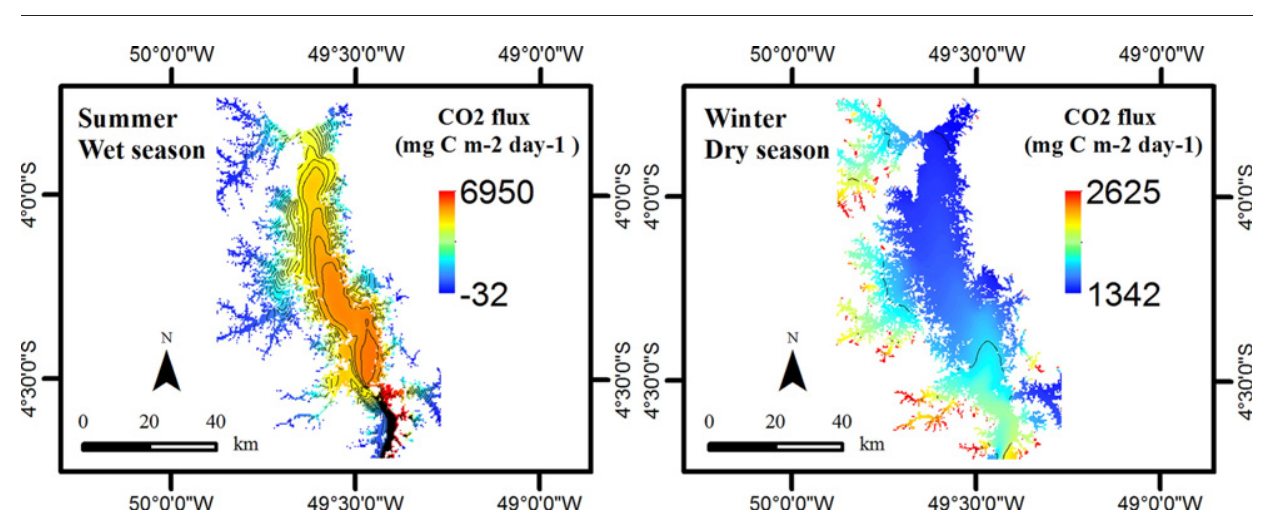

\begin{abstract}
A B S T R A C T
We used a three-dimensional model to assess the dynamics of diffusive carbon dioxide flux $\left(F_{\mathrm{CO} 2}\right)$ from a hydroelectric reservoir located at Amazon rainforest. Our results showed that for the studied periods (2013 summer/ wet and winter/dry seasons) the surface averaged $F_{\mathrm{CO} 2}$ presented similar behaviors, with regular emissions peaks. The mean daily surface averaged $F_{\mathrm{CO} 2}$ showed no significant difference between the seasons $(p>0.01)$, with values around $-1338 \mathrm{mg} \mathrm{C} \mathrm{m}-2$ day -1 (summer/wet) and $-1395 \mathrm{mg} \mathrm{C} \mathrm{m}-2$ day -1 (winter/ dry). At diel scale, the $F_{\mathrm{CO} 2}$ was large during the night and morning and low during the afternoon in both seasons. Regarding its spatial distribution, the $F_{\mathrm{CO} 2}$ showed to be more heterogeneous during the summer/wet than during the winter/dry season. The highest $F_{\mathrm{CO} 2}$ were observed at transition zone $(-300 \mathrm{mg} \mathrm{C} \mathrm{m}-2 \mathrm{~h}-1)$ during summer and at littoral zone $(-55 \mathrm{mg} \mathrm{C} \mathrm{m}-2 \mathrm{~h}-1)$ during the winter. The total $\mathrm{CO}_{2}$ emitted by the reservoir along 2013 year was estimated to be $1.1 \mathrm{Tg} C$ year -1 . By extrapolating our results we found that the total carbon emitted by all Amazonian reservoirs can be around $7 \mathrm{Tg} C$ year -1 , which is $22 \%$ lower than the previous published estimate. This significant difference should not be neglected in the carbon inventories since the carbon emission is a key factor when comparing the environmental impacts of different sources of electricity generation and can influences decision makers in the selection of the more appropriate source of electricity and, in case of hydroelectricity, the geographical position of the reservoirs.
\end{abstract}

(c) 2016 Elsevier B.V. All rights reserved.

\footnotetext{
* Corresponding author.

E-mail addresses: mpedroso@dsr.inpe.br (M.P. Curtarelli), igoroga@gmail.com (I. Ogashawara), carlos@dsr.inpe.br (C.A.S. de Araújo), loren@dsr.inpe.br (J.A. Lorenzzetti), joaquim@dpi.inpe.br (J.A.D. Leão), enner@fct.unesp.br (E. Alcântara), stech@dsr.inpe.br (J.L. Stech).
} 


\section{Introduction}

It has been a little over twenty years since the publication of the pioneering work by Rudd et al. (1993) which addressed the problem of greenhouse gases (GHG) emissions from reservoirs of hydroelectric power plants. Since then, this subject has been the focus of work and research of scientists and environmental managers in many countries such as: Canada (Duchemin et al., 1995), United States (Soumis et al., 2004), Brazil (Rosa and Schaeffer, 1995; Rosa et al., 2004; Santos et al., 2006), Panama (Keller and Stallard, 1994), French Guiana (Galy-Lacaux et al., 1997; Galy-Lacaux et al., 1999), Sweden (Aberg et al., 2004), Finland (Huttunen et al., 2002) and China (Xiao et al., 2013). Despite of the great progress achieved in the past two decades of research there are still significant gaps in our knowledge regarding the temporal and spatial variability of the GHG emissions. These gaps are even larger in areas with low monitoring capabilities due to the difficult access, for example, the hydroelectric reservoirs within the Amazon biome.

According to the current estimates the hydroelectric reservoirs located in the Amazon region are responsible for emitting $9 \mathrm{TgC}$ year ${ }^{-1}$, being $8 \mathrm{TgC}$ year ${ }^{-1}$ as carbon dioxide $\left(\mathrm{CO}_{2}\right)$ and $1 \mathrm{Tg}^{\mathrm{C}}$ year ${ }^{-1}$ as methane $\left(\mathrm{CH}_{4}\right)$ (Barros et al., 2011). It is noteworthy that, despite having their merits, this estimate is limited, since it was based on results published in the literature obtained by extrapolation of data collected sparsely in space and time domains, and for reservoirs of different ages (Abril et al., 2005; Guérin et al., 2006; Keller and Stallard, 1994; Kemenes et al., 2007; Lima, 2005; Lima et al., 1998; Rosa et al., 2004; Santos et al., 2006; St Louis et al., 2000; Therrien, 2005). Theses simplification can greatly impact the $\mathrm{C}$ emission estimative, since the flux of $\mathrm{CO}_{2}$, which is the main source of $C$ by the reservoir surface in the Amazonian region, have high spatial and temporal variability.

In the case of tropical reservoirs located outside the Amazon biome, recent studies such as those presented by Roland et al. (2010); Bergier et al. (2011) and Pacheco et al. (2015) showed that the diffusive flux of $\mathrm{CO}_{2}$ has great spatial and temporal variability. In hydroelectric reservoirs located in the Brazilian Cerrado biome the diffusive flux of $\mathrm{CO}_{2}$ can vary between $13 \%$ and $46 \%$ in space (Roland et al., 2010) and more than $100 \%$ throughout the day (Bergier et al., 2011). Ometto et al. (2013) also showed that for hydroelectric reservoirs located in the Cerrado biome the $\mathrm{CO}_{2}$ flux presented a negative correlation with the reservoir age. In the Funil reservoir, located in the Brazilian Mata Atlântica biome the diffusive flux of $\mathrm{CO}_{2}$ can vary by more than $200 \%$ in space depending on the season (Pacheco et al., 2015). Consequently, different conclusions can be drawn with respect to the carbon emissions in these environments, depending on the sampled place, day of year and hour of data collection.

A more comprehensive dataset recently collected under the project "Greenhouse gas emissions in hydroelectric plants reservoirs" (hereafter Balcar Project) revealed new aspects regarding spatial and temporal variability of $\mathrm{C}$ emissions in Amazonian hydroelectric reservoirs (Brazil/ MME, 2014). Nevertheless the Balcar Project dataset does not have the spatial and time resolutions needed to investigate the variability of emissions at finer temporal and spatial scales, such as the diel and daily scales. This limitation is a major drawback for the investigation of daily and diel variations of $\mathrm{CO}_{2}$ flux and hence a more accurate assessment of total carbon emissions in these environments.

The above studies highlight the need for intensive data collection in both time and space domains to reduce uncertainties in the estimation of carbon emissions by Amazonian reservoirs, as well as to assess the main environmental factors regulating these emissions. However this type of collection is not always possible, either due to high human and financial resource implications, or by the difficulty of access to the study region. Therefore it is necessary to the development an application of new methodologies for the study of carbon emissions in Amazonian hydroelectric reservoirs.

A new approach which has high potential of application to study the carbon emission in Amazonian reservoirs, however not explored yet, is the use of ecological modeling (Tremblay et al., 2005; Marti et al., 2007; Santoso et al., 2015). Mooij et al. (2010) and Menshutkin et al. (2014) provided a complete review of ecological models, listing the main models used in the literature, its main features and capabilities, and its advantages and limitations. As one of main advantage in using ecological models to study the carbon emissions from hydroelectric reservoirs is the ability to perform simulations at different temporal and spatial scales, to investigate different processes occurring in the water column in an integrated manner, and the possibility of investigating different scenarios (e.g., climate change, eutrophication, extreme events, etc.).

Taking into account the context described above, we hypothesized that due to the large size of these reservoirs and the variation in the water level over the year, the simplification made by Barros et al. (2011) is not appropriate for Amazonian reservoirs. A sampling carried out in a few places in the reservoir, at different times of day and in a few days of the year has no potential to verify this claim. On the other hand, the use of numerical models has been shown great potential for the study of different aspects of tropical hydroelectric reservoirs (Curtarelli et al., 2014a, 2014b, 2015a; Pacheco et al., 2015). However, until now, no study seems to have been done using this approach to investigate the spatial and temporal dynamics of carbon emissions from hydroelectric reservoirs located in the Amazon region. In this context, this work has as main innovation the use of numerical modeling in order to better understand the spatial and temporal variability of the diffusive $\mathrm{CO}_{2}$ flux of hydroelectric reservoirs located in the Amazon. The main objective of this work is to study the dynamics of spatial and temporal variability of the diffusive flux of $\mathrm{CO}_{2}$ in the Tucurui reservoir throughout the summer and winter seasons.

A summary of some important environmental and limnological characteristics of the study area is presented in the following section. In sequence, we described the methodology used in this research; the dataset, the characteristics and configuration of the model, and the methods used to analyze the simulations results are also presented in this section. We then presented the results of simulations of $\mathrm{CO}_{2}$ flux for the two periods analyzed and the results of correlation analysis between simulated $\mathrm{CO}_{2}$ flux and pre-selected predictive variables. In the last section, we discuss our results and compare them to previous studies conducted at THR. We also show the implications of our results for the global assessments of carbon emissions by Amazonian hydroelectric reservoirs.

\section{Site description}

The studied hydroelectric reservoir was the Tucuruí Hydroelectric Reservoir (THR), located within the Amazon biome, between $3^{\circ} 43^{\prime} 2^{\prime \prime} \mathrm{S}$, $49^{\circ} 59^{\prime} 15^{\prime \prime} \mathrm{W}$ and $4^{\circ} 52^{\prime} 31^{\prime \prime} \mathrm{S}, 49^{\circ} 9^{\prime} 13^{\prime \prime} \mathrm{W}$, Pará State, North of Brazil (see Fig. 1). Among the reasons for choosing THR for this study was that it is one of the largest reservoirs in the Amazon region (surface area around $2500 \mathrm{~km}^{2}$ and volume around 52 billion $\mathrm{m}^{3}$ at the maximum operational water level, $74 \mathrm{~m}$ above mean sea level) and for which a long term environmental dataset is available. Several studies have been conducted in the THR regarding $C$ emissions and it was the focus of a warm discussion in the scientific literature in the last decade (Rosa and Schaeffer, 1995; Fearnside, 1995 , 2002; Rosa et al., 2006).

The THR can be classified as a monomictic (Tundisi et al., 2005) and mesotrophic (Lobato et al., 2014) water body, presenting frequent algae blooms during the wet season (Tavares, 2011). The climate in the THR region can be classified as tropical with monsoons (Am) (Peel et al., 2007) with average monthly air temperature ranging from $24.5^{\circ} \mathrm{C}$ (February) to $28{ }^{\circ} \mathrm{C}$ (October) and an annual average of $26.5^{\circ} \mathrm{C}$. The rainfall, which exceeds $2000 \mathrm{~mm}$ year $^{-1}$, is distributed irregularly with two well-defined seasons: wet (from October to April) and dry (from May to September). From the operational point of view the THR shows four distinct phases along the year: dry (Oct-Dec), filling (Dec-Mar), full (Mar-Jul) and emptying (Jul-Oct). The residence time ranges from 


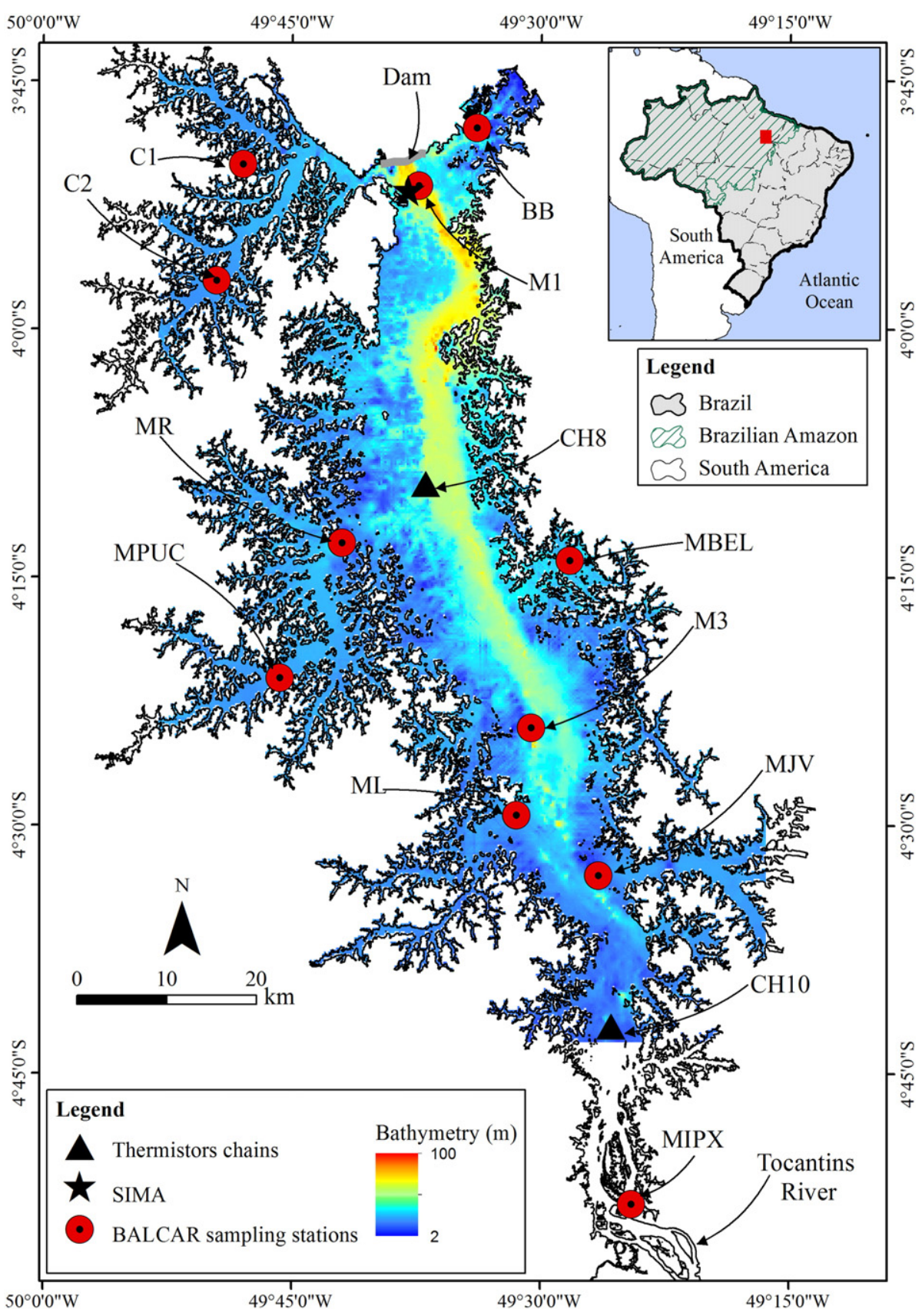

Fig. 1. Study area: (a) THR location at Brazilian Amazon, and (b) THR boundaries and bathymetry view.

30 days during the Austral summer to 180 days during the Austral winter (Fearnside, 2002).

The diffusive $\mathrm{CO}_{2}$ fluxes show quite variable spatial and seasonal patterns (Brazil/MME, 2014). From seasonal point of view the average diffusive $\mathrm{CO}_{2}$ flux ranges from around $1000 \mathrm{mg} \mathrm{C} \mathrm{m}^{2}$ day ${ }^{-1}$ (Austral winter) to around $600 \mathrm{mg} \mathrm{C} \mathrm{m}{ }^{2}$ day $^{-1}$ (Austral autumn); during the summer and spring the average diffusive $\mathrm{CO}_{2}$ flux is around $900 \mathrm{mg} \mathrm{Cm} \mathrm{Cm}^{2-}$ day $^{-1}$. The high spatial heterogeneity of $\mathrm{CO}_{2}$ flux is observed during the summer and autumn periods.

\section{Materials and methods}

\subsection{Reservoir bathymetry}

A bathymetric grid with a $400 \times 400 \mathrm{~m}$ spatial resolution, resulting in 47,128 grid points, was obtained from the spatial interpolation of depth samples collected with a GPSMap 520s Garmin ${ }^{\circledR}$ ecobathymeter (Olathe, Kansas, USA) during a single field expedition conducted between 3 and 16 July 2013. Detailed information about the interpolation procedure and the validation of bathymetric grid can be found in Curtarelli et al. (2015b). The root-mean-square-error (RMSE) of the interpolated bathymetric grid was $<1 \mathrm{~m}$.

\subsection{Surface meteorology dataset}

The surface meteorology dataset used in this study were acquired in part by an autonomous system moored within THR (i.e., wind speed and direction, air temperature, relative humidity, atmospheric pressure and incoming shortwave radiation) and complemented with information derived from remote sensing products (i.e. cloud cover and rainfall) (Fig. 2a-p). The autonomous system, called "Integrated System for Environmental Monitoring" (SIMA, from the Portuguese spelling, 


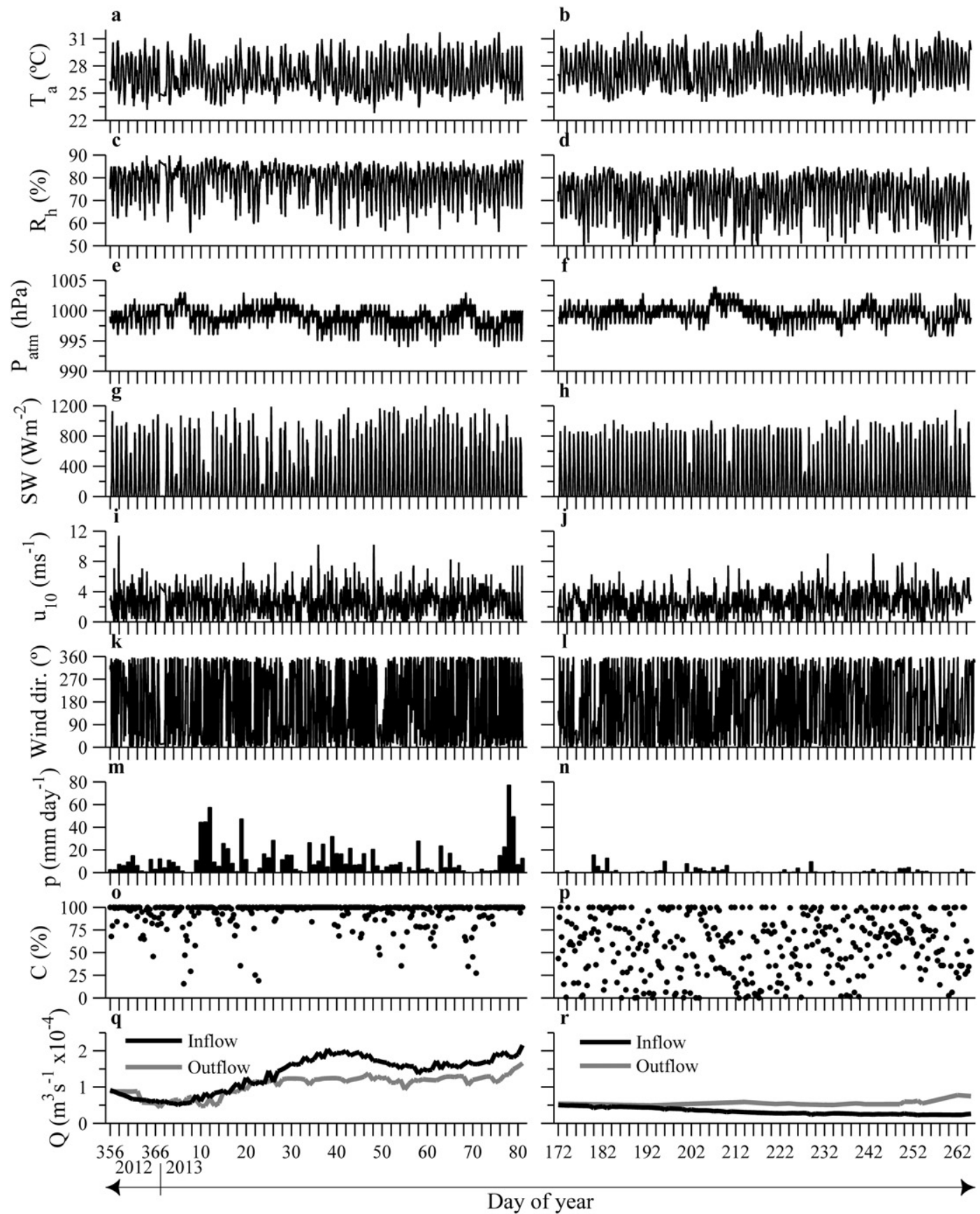

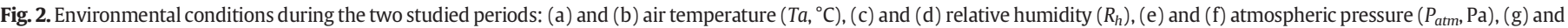

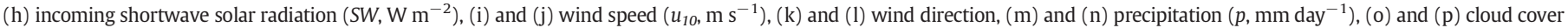

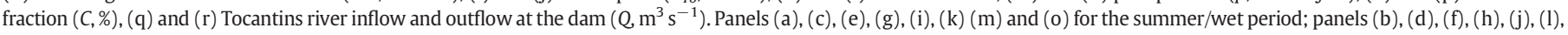
$(\mathrm{n})$ and $(\mathrm{p})$ for the winter/dry period.

Stech et al., 2006; Alcântara et al., 2013), acquired hourly data between 21 December 2012 and 21 September 2013. The meteorological data collected by SIMA (except wind speed and direction) were recorded every hour, as a result from a mean of 30 samples collected by a burst sampling of $0.3 \mathrm{~ms}$ duration at a $10 \mathrm{~ms}$ rate. The wind speed and direction were collected every $30 \mathrm{~s}, 10$ times before and 10 times after the hourly recording; the mean value of these 21 samples was recorded. The primary characteristics of the meteorological sensors used are summarized in Table 1, and the SIMA location within the THR is shown in Fig. 1.

The cloud cover fraction and precipitation data were derived from remote sensing standard products. Cloud cover data was retrieved using the Moderate Resolution Imaging Spectroradiometer (MODIS) level 2 cloud mask product (named M*D35L2) (Ackerman et al., 1998). This product is generated up to four times each day (i.e., 10:30 h, 13:30 h, 23:30 h and 01:30 h) and is delivered in a georeferenced grid with a $1 \mathrm{~km}$ spatial resolution in a sinusoidal projection. Precipitation data was acquired using the Tropical Rainfall Measuring Mission (TRMM) 3B42 product (Huffman et al., 2007) version 6, which provides daily accumulated precipitation rate in a georeferenced grid with a $25 \mathrm{~km}$ resolution. Both remote sensing-derived data were reprojected to the Universal Transverse Mercator (UTM) coordinate system (zone 22 south), using the World Geodetic System (WGS-84) datum as a reference, and converted to a raster image. A MATLAB ${ }^{\circledR}$ routine was specially developed for computing cloud cover fraction and precipitation rate over THR. 
Table 1

Technical specification of the SIMA sensors.

\begin{tabular}{|c|c|c|c|c|}
\hline Sensor & Manufacturer/model & Range & Accuracy & Height \\
\hline $\begin{array}{l}\text { Thermo } \\
\text { hygrometer }\end{array}$ & Rotronic MP 101A & $\begin{array}{l}-40 \text { to } 60{ }^{\circ} \mathrm{C} \\
0 \text { to } 100 \%\end{array}$ & $\begin{array}{l} \pm 0.3{ }^{\circ} \mathrm{C} \\
\pm 1 \%\end{array}$ & $3 \mathrm{~m}$ \\
\hline Anemometer & RM Young 05106 & $\begin{array}{l}0 \text { to } 100 \mathrm{~m} \mathrm{~s}^{-1} \\
0 \text { to } 360^{\circ}\end{array}$ & $\begin{array}{l} \pm 0.3 \mathrm{~m} \mathrm{~s}^{-1} \\
\pm 3^{\circ}\end{array}$ & $3 \mathrm{~m}$ \\
\hline Pyranometer & Novalynx 840-8102 & 0 to $1500 \mathrm{~W} \mathrm{~m}^{-2}$ & $<1 \mathrm{~W} \mathrm{~m}^{-2}$ & $3 \mathrm{~m}$ \\
\hline $\begin{array}{c}\text { Barometric } \\
\text { pressure }\end{array}$ & Vaisala PTB 110 & 800 to $1060 \mathrm{hPa}$ & $\begin{array}{l} \pm 0.3 \mathrm{hPa} \\
\text { at } 20{ }^{\circ} \mathrm{C}\end{array}$ & $3 \mathrm{~m}$ \\
\hline
\end{tabular}

\subsection{Operational dataset}

The operational dataset (Fig. $2 \mathrm{q}$ and r) used in this study comprises daily inflow, outflow and water level time series provided by the "Centrais Elétricas do Norte do Brasil S.A." (Eletronorte), the company which oversees the reservoir. The data is available on line at: www. eln.gov.br/opencms/export/sites/eletronorte/pilares/geracao/estados/ tucurui. For this study we used the data provided between 21 December 2012 and 21 September 2013.

\subsection{Limnological and $\mathrm{CO}_{2}$ emission datasets}

The limnological and $\mathrm{CO}_{2}$ emission datasets used in this study come from two different sources: (1) the database of Balcar project, which comprises limnological and GHG emission data collected by different Brazilian research institutions (Brazil/MME, 2014); and (2) temperature data collected by thermistors chains anchored in the reservoir. The Balcar project database is available online and can be accessed by means of a previous registration (http://www.dsr.inpe.br/hidrosfera/ balcar/). More details about Balcar project can be found in Brazil/MME (2014).

The Balcar project data used in this study were collected by Eletronorte team, at 11 different sampling points, between 2011 and 2012 during the summer and winter period (see Fig. 1 for the location of Eletronorte sampling stations). Limnological data were measured at the Tocantins River upstream of the reservoir and in the water column of THR at different depths while the $\mathrm{CO}_{2}$ emission data where measured at air-water interface. The limnological dataset includes the following parameters: (1) water temperature; (2) dissolved oxygen (DO); (3) chlorophyll-a (Chl-a); (4) pH; (5) phosphate $\left(\mathrm{PO}_{4}^{3-}\right)$; (6) dissolved organic phosphorus (DOP); (7) particulate organic phosphorus (POP); (8) particulate inorganic phosphorus (PIP); (9) nitrate $\left(\mathrm{NO}^{3-}\right)$; (1) ammonium ( $\left.\mathrm{NH}_{4}^{+}\right)$; (11) particulate organic nitrogen (PON); (12) dissolved organic nitrogen (DON); (13) dissolved organic carbon (DOC); (14) particulate organic carbon (POC); (15) particulate inorganic carbon (PIC); and dissolved inorganic carbon (DIC). The $\mathrm{CO}_{2}$ emission dataset include diffusive flux (in units of $\mathrm{mg} \mathrm{C} \mathrm{m}^{-2}$ day $^{-1}$ ) measured using static floating chambers by Eletronorte team.
Time series of water temperature profiles' were collected hourly between 21 December 2012 and 21 September 2013 by two thermistor chains: one installed at the river-reservoir transition zone $(\mathrm{CH} 10$ station), and one installed in the main body of the reservoir ( $\mathrm{CH} 8$ station) (see Fig. 1 for thermistor chains location). Each thermistor chain had 15 HOBO Onset ${ }^{\circledR}$ U22-001-Water Temp Pro v2 probes (Bourne, Massachusetts, USA). These thermistors operate between $-40{ }^{\circ} \mathrm{C}$ and $50{ }^{\circ} \mathrm{C}$ with a factory-specified accuracy of $\pm 0.2^{\circ} \mathrm{C}$. At CH10, thermistors were installed at $0.3,1,2,3,4,5,6,7,8,10,12,14,16,18$, and $20 \mathrm{~m}$ depths. At CH8, thermistors were installed at $0.3,1,2,4,6,8,10,12$, $14,16,18,20,25,30$ and $35 \mathrm{~m}$ depths. In addition to the two thermistor chains, a YSI ${ }^{\circledR} 6600$ V2 sonde (Yellow Springs, Ohio, USA) was used to collect the hourly water surface temperature (at a $0.5 \mathrm{~m}$ depth) at the SIMA location. The YSI sonde temperature sensor operates between $-5{ }^{\circ} \mathrm{C}$ and $60{ }^{\circ} \mathrm{C}$ with a factory-specified accuracy of $\pm 0.15^{\circ} \mathrm{C}$.

Fig. 3 shows the mean values of water quality parameter measured at the Tocantins River (station M5, see Fig. 1 for location) while Fig. 4 shows the water quality parameters profiles measured in the water column of THR (stations M1, MR, MPUC, M3, MBEL, ML, MJV and in the thermistors chains $\mathrm{CH} 10$ and $\mathrm{CH} 8$, see Fig. 1 for locations). The Table 2 summarizes the $\mathrm{CO}_{2}$ emission dataset.

\subsection{Ecological model}

We used the Computational Aquatic Ecosystem Dynamic Model v3.2 (CAEDYM, Hipsey et al., 2014) coupled to the Estuary and Lake Computer Model v2.2 (ELCOM, Hodges et al., 2000) to simulate the diffusive atmospheric $\mathrm{CO}_{2}$ flux from THR to the atmosphere. The choice of ELCOM-CAEDYM (ELCD) model to simulate the behavior of diffusive $\mathrm{CO}_{2}$ flux in the THR was based on technical and economic criteria. We also took into consideration the literature reviews performed by Mooij et al. (2010) and Menshutkin et al. (2014). The main points considered for the choice of the ELCD model were: (1) ELCD has the ability to simulate the dynamics of carbon in the water column and the atmospheric $\mathrm{CO}_{2}$ flux; (2) ELCD is a tri-dimensional (3-D) model, suitable for large reservoirs with a complex morphology (Leon et al., 2008), as is the case of Tucuruí reservoir; (3) ELCD model has a good documentation and is easily accessible; (4) ELCD has friendly graphical interface, which facilitates the configuration and processing of data for the simulations and enables rapid visualization of the results; and (5) ELCD is widely used in the scientific literature (Romero et al., 2004; Bruce et al., 2006; Marti et al., 2007; Missaghi and Hondzo, 2010; Trolle et al., 2011; Santoso et al., 2015).

ELCOM is a three-dimensional hydrodynamic model which solves unsteady, coupled, Reynolds-averaged Navier-Stokes and scalar transport equations using hydrostatic and Boussinesq approximations. The numerical discretization uses an Euler-Lagrange approach for momentum advection, which was adapted from Casulli and Cheng (1992). Scalar advection is based on the ULTIMATE-QUICKEST method proposed by Leonard (1991). The vertical mixing is modeled based on one dimensional approach described by Imberger and Patterson (1989). The surface heat budget components are computed using standard bulk

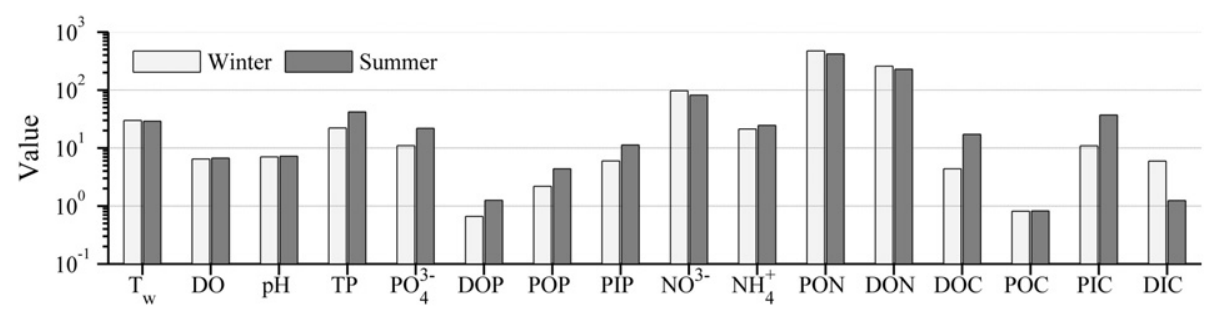

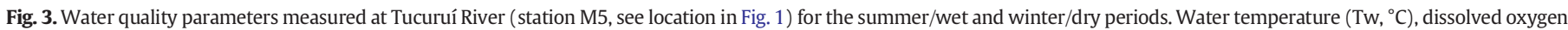

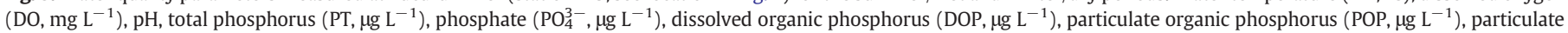

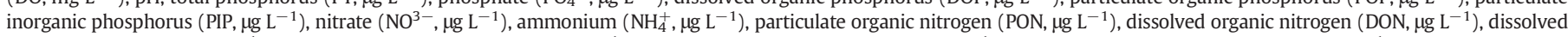
organic carbon (DOC, $\mathrm{mg} \mathrm{L}^{-1}$ ), particulate organic carbon (POC, $\mathrm{mg} \mathrm{L}^{-1}$ ), particulate inorganic carbon (PIC, $\mathrm{mg} \mathrm{L}^{-1}$ ) and dissolved inorganic carbon (DIC, $\mathrm{mg} \mathrm{L}^{-1}$ ). 

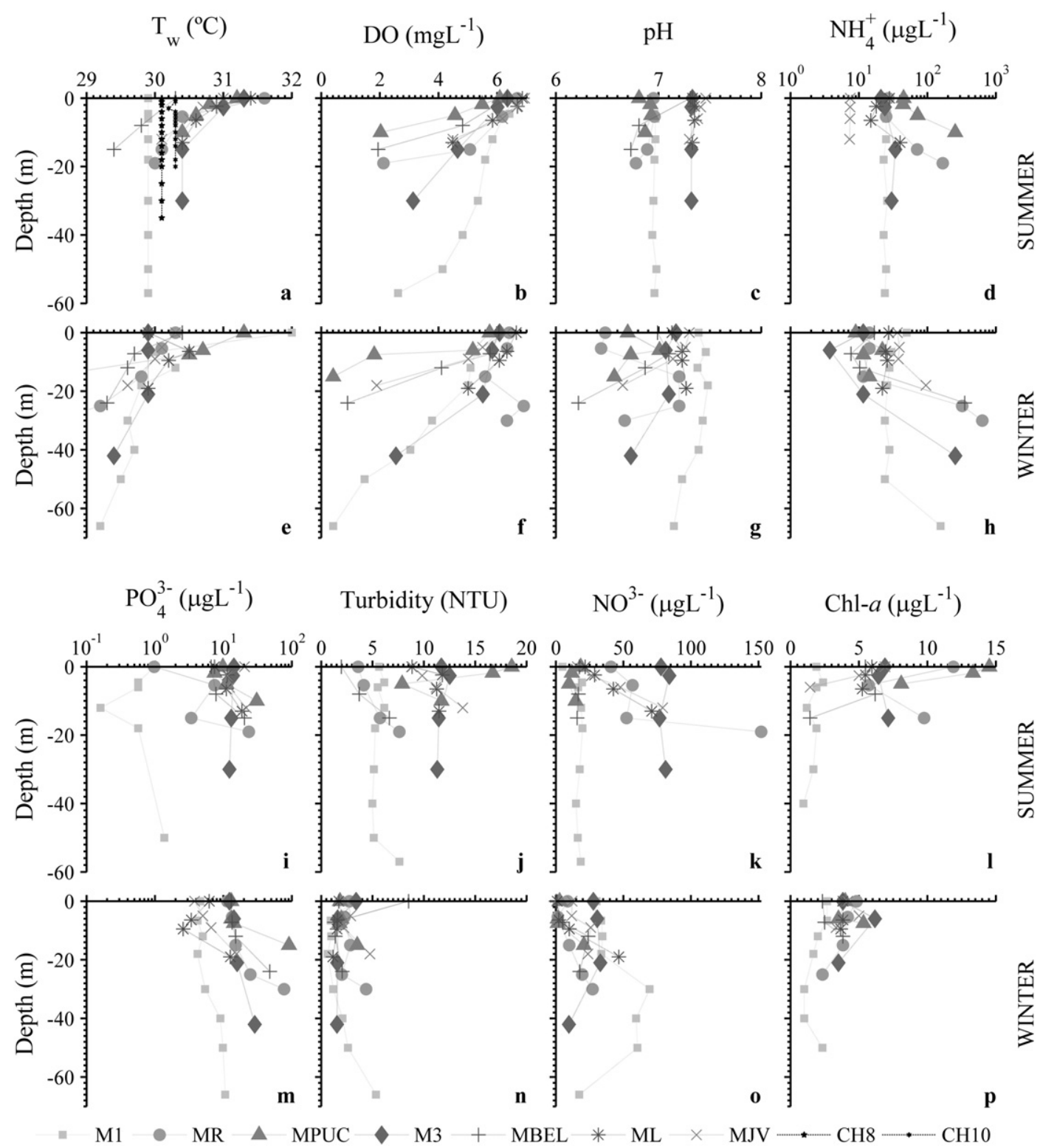

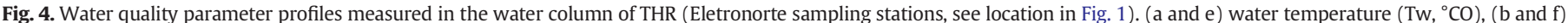

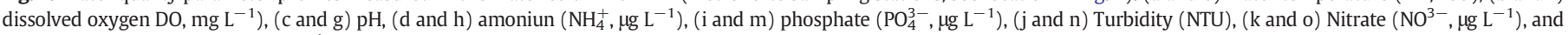
(l and p) Chlorophyll- $a$ (Chl- $\left.a, \mu \mathrm{g} \mathrm{L}^{-1}\right)$.

transfer models, which are parameterized as functions of meteorological variables (Imberger and Patterson, 1989). The model simulates the atmospheric stability effects on surface heat fluxes using the iterative procedure described in Hicks (1975). The fraction of shortwave radiation that penetrates the water column decays following the BeerLambert-Bouguer law.

CAEDYM is an aquatic ecological model which can be dynamically coupled to ELCOM for simulation of ecological and bio-chemical processes within lakes, reservoirs and costal zones. This model has been widely cited in the literature, and was used for different studies such as: the evaluation of water quality in lakes (Gal et al., 2009; Missaghi and Hondzo, 2010), internal nutrients cycling (Bruce et al., 2006; Spillman et al., 2007), algae bloom events (Robson and Hamilton, 2004; Silva et al., 2014), among other studies. The main processes included in the carbon cycle modeling by CAEDYM according to Hipsey et al. (2014) are: (1) atmospheric fluxes of $\mathrm{CO}_{2}$; (2) carbonate buffer system induced DIC variations; (3) mineralization of DOC to DIC; (4) biological uptake of DIC by phytoplankton, macroalgae and macrophytes; (5) dissolved sediment fluxes of DIC and DOC; (6) decomposition of POC into DOC; (7) biological mortality and excretion into the DOC and POC pools; (8) settling of POC; and (9) resuspension of POC. The diffusive atmospheric $\mathrm{CO}_{2}$ flux, $F_{\mathrm{CO} 2}\left(\mathrm{~g} \mathrm{C} \mathrm{m}^{-2} \mathrm{~s}^{-1}\right)$, is modeled using the Wanninkhof equation's (Wanninkhof, 1992):

$F_{\mathrm{CO} 2}=k_{\mathrm{co} 2} K_{0}\left(p \mathrm{CO}_{2}^{\text {air }}-p C \mathrm{O}_{2}^{\text {water }}\right)$

where $p_{\mathrm{CO} 2}$ is the partial pressure of $\mathrm{CO}_{2}$ (atm). Gaseous and aqueous phase $\mathrm{CO}_{2}$ values are related by Henrys Law for calculation of $p_{\mathrm{CO} 2}$. Positive values of $F_{\mathrm{CO} 2}$ indicate that reservoir acts as a carbon sink while negative values indicate that reservoir acts as a source of carbon to the atmosphere. The gas transfer velocity, $k_{\mathrm{CO} 2}\left(\mathrm{~m} \mathrm{~s}^{-1}\right)$, is calculated as function of wind speed and water column stability:

$k_{\mathrm{CO} 2}=2.2 \times 10^{-5} \frac{u_{10}^{2}}{\sqrt{\mathrm{Sc}}}$ 
Table 2

Summary of diffusive $\mathrm{CO}_{2}$ flux measured in THR using floating chambers. The locations of sampling stations are shown in Fig. 1. Negative values indicate $\mathrm{CO}_{2}$ evasion from reservoir.

\begin{tabular}{lcc}
\hline Sampling station & $\begin{array}{l}F_{\mathrm{CO} 2}(\mathrm{mg} \mathrm{C} \mathrm{m} \\
\text { summer/wet }\end{array}$ & $\begin{array}{l}F_{\mathrm{CO} 2}\left(\mathrm{may}^{-1}\right) \\
\text { winter } / \text { dry }\end{array}$ \\
\hline C1 & -40.46 & -3193.77 \\
C2 & -36.55 & -446.12 \\
BB & -31.55 & -786.67 \\
M1 & -39.22 & -1590.88 \\
MR & -19.36 & -257.58 \\
MBEL & -40.66 & -1008.23 \\
MPUC & -140.89 & -563.48 \\
M3 & -2.51 & $-10,036.85$ \\
MJV & -27.18 & -5543.70 \\
\hline
\end{tabular}

where $u_{10}$ is the wind speed $10 \mathrm{~m}$ above the water surface $\left(\mathrm{m} \mathrm{s}^{-1}\right)$ and Sc is the Schmidt number:

$$
\begin{aligned}
S C= & \left(0.9+\frac{S}{350}\right) \times\left[2073.1-125.62 \times\left(T_{w}\right)+3.6276 \times\left(T_{w}^{2}\right)\right. \\
& \left.-0.043219 \times\left(T_{w}^{3}\right)\right]
\end{aligned}
$$

where $S$ in the salinity of water (psu) and $T_{w}$ is the water temperature $\left({ }^{\circ} \mathrm{C}\right)$. The solubility product of $\mathrm{CO}_{2}, K_{0}\left(\mathrm{~mol} \mathrm{~L}^{-1} \mathrm{~atm}^{-1}\right)$, is calculated according to Weiss (1974):

$K_{0}=e^{\left[-58.0931+90.5069 \times\left(\frac{100}{\theta_{W}}\right)+22.94 \times \ln \left(\frac{\theta_{W}}{100}\right)+0.027766 \times S-0.025888 \times S \times\left(\frac{\theta_{W}}{100}\right)+0.0050578 \times S \times\left(\frac{\theta_{W}}{100}\right)^{2}\right]}$

where $\theta_{w}$ is the water temperature in degrees Kelvin (K). The complete set of equations used by CAEDYM to model the carbon cycle is presented by Hipsey et al. (2014).

\subsection{Tucuruí reservoir simulations}

The simulation of $F_{\mathrm{CO} 2}$ was performed for two periods: (1) summer/ wet period, from 21 December 2012-21 March 2013, and (2) winter/ dry period, from 21 June to 21 September 2013. To account for unstable atmospheric conditions, ELCOM atmospheric stability submodel was activated during the simulations; this procedure is appropriate in cases in which the meteorological sensors are located within the internal boundary layer over the lake surface and the data are collected at subdaily intervals (Imberger and Patterson, 1989). Additionally, considering the weak stratification $\left(\sim 0.1{ }^{\circ} \mathrm{C} \mathrm{m}^{-1}\right)$ observed in the main body of the THR ( $\mathrm{CH} 8$ station), we observed that the reduced gravity has typical values on the order of $\mathrm{O}\left(10^{-3} \mathrm{~m} \mathrm{~s}^{-2}\right)$. The reservoir depth has values on the order of $\mathrm{O}\left(10^{0} \mathrm{~m}\right)$ and the Coriolis parameter has values on the order of $\mathrm{O}\left(10^{-5} \mathrm{~s}^{-1}\right)$. These typical values provided internal wave velocities on the order of $\mathrm{O}\left(10^{-2} \mathrm{~m} \mathrm{~s}^{-1}\right)$ and a Rossby radius of deformation on the order of $\mathrm{O}\left(10^{3} \mathrm{~m}\right)$ which is smaller than the width of the reservoir $\sim \mathrm{O}\left(10^{4} \mathrm{~m}\right)$. Hence, rotational effect should not be neglected, and ELCOM Coriolis submodel was activated during the simulations.

We considered only one inflow (the Tocantins River) and one outflow (located at the dam) during the simulations. The numerical domain was discretized on a uniform horizontal grid containing $400 \mathrm{~m} \times 400 \mathrm{~m}$ cells based on available bathymetric data. In the vertical direction, we used a non-uniform grid resolution; the thickness of the vertical layers increased smoothly with the depth from $0.1 \mathrm{~m}$ (upper water column) to $5 \mathrm{~m}$ (bottom layer) resulting in a total of 74 layers. These grid configurations were chosen to optimize the model performance and to reduce the computational cost. The physical parameters used in this study (Table 3a) were the same used by Curtarelli et al. (2014) which calibrated and validated ELCOM to simulate the impacts of mesoscale convective systems on the energy balance and diurnal mixed layer dynamics of THR.
The CAEDYM model was configured to simulate only the labile fractions of POC and DOC. Based on the study of Tavares (2011), which characterized the structure of the micro phytoplankton community in the THR, we selected only one algae group to be simulated: the blue-green algae Microcystis Auruginosa which is the most frequent (i.e., present in $80 \%$ of samples) and the dominant (i.e., account for more than $70 \%$ of individuals within one sample). For this algae group, the vertical migration of phytoplankton and photo-inhibition were considered during the simulation. We also considered the resuspension and settling of POC during the simulation. A static sediment model was chosen to simulate the dissolved sediment fluxes of DIC and DOC. Table 3 shows a summary of biological (Table $3 \mathrm{~b}$ ), geochemical (Table $3 \mathrm{c}$ ) and sediment (Table 3d) parameters used for the simulations. The parameter values were chosen based on literature review and in situ measurements conducted at THR.

The ELCD coupled model was forced using the operational data provided by Eletronorte (daily inflow and outflow), the surface meteorology dataset collected by SIMA (wind speed and direction, air temperature, relative humidity, atmospheric pressure and incoming shortwave radiation) and derived from remote sensing data (cloud cover and rainfall) (see Fig. 2), and the nutrients and carbon inputs from Tocantins River (see Fig. 3). The meteorological variables were considered uniform across the numerical domain. This assumption is reasonable since the meteorological variables present a quite homogeneous pattern over the THR region. The concentration of nutrients and carbon inputs by Tocantins River were considered constant along each season.

The initial conditions for the two simulated periods were established based on in situ profile measurements conducted by Eletronorte and temperature data collected by the two thermistor chains (see Fig. 1 for the locations of Eletronorte sampling stations and thermistor chains, and Fig. 4 for the water quality profiles). To spin-up the circulation patterns and water temperature gradients, the simulation was initiated 10 days before the periods of interest. The time step used was $120 \mathrm{~s}$ and the outputs were preprogramed to be saved at each $30 \mathrm{~min}$. The simulations outputs included the surface averaged $F_{\mathrm{CO} 2}$ time series and spatially distributed $F_{\mathrm{CO} 2}$ values, both in units of $\mathrm{g} \mathrm{C} \mathrm{m}^{-2} \mathrm{~s}^{-1}$. The simulations results were post processed using a MatLab® routine in order to convert and aggregate the fluxes to units of $\mathrm{mg} \mathrm{C} \mathrm{m}^{-2} \mathrm{~h}^{-1}$ and $\mathrm{mg} \mathrm{C} \mathrm{m}^{-2}$ day $^{-1}$.

The results of simulations for both periods were validated by the comparison to the $\mathrm{CO}_{2}$ diffusive flux measurements carried out by Eletronorte team within the Balcar project (2011-2012 year) using static floating chambers (see Table 2) and water level time series measured at the dam with daily frequency provided by Eletronorte. For the $F_{\mathrm{CO} 2}$ comparison, we selected the simulated values at the same location of Eletronorte sampling stations (see Fig. 1) from the same day of year and time of sampling collection to compose our validation dataset. Besides the time lapse (i.e., 1 year) between the Balcar data collection and our simulation year, we highlight that no significant changes were observed in the land use and land cover (LULC) of the THR drainage basin ( $<5 \%$ of LULC change). We also emphasize that no significant differences were observed among meteorological variables for 2012 and 2013 ( $t$-test, $n=365, p>0.01$ ). The LULC change was evaluated by the MODIS Land Cover Type product (named MCD12Q1) (Friedl et al., 2010), which describes land cover properties derived from observations spanning a year's input of MODIS data. The primary land cover scheme identifies 17 land cover classes defined by the International Geosphere Biosphere Program (IGBP), which includes 11 natural vegetation classes, 3 developed and mosaicked land classes, and 3 non-vegetated land classes. The differences among meteorological variables for 2012 and 2013 were evaluated by a pairwise comparison between daily readings of air temperature, precipitation, wind speed, atmospheric pressure and relative humidity, measured at THR dam and provided by Brazilian Institute of Meteorology (INMET, from Portuguese spelling). Taking into account that the LULC and meteorology were similar for both years (2012 and 2013), we expected that the $\mathrm{CO}_{2}$ emissions observed during 
Table 3

Summary of selected parameters used in ELCOM-CAEDYM simulations.

\begin{tabular}{|c|c|c|c|c|c|}
\hline & Symbol & Units & $\begin{array}{l}\text { Assigned } \\
\text { value }\end{array}$ & $\begin{array}{l}\text { Values from } \\
\text { field/literature }\end{array}$ & Source \\
\hline \multicolumn{6}{|l|}{ a) Physical parameters } \\
\hline Albedo for shortwave radiation & $\alpha_{\mathrm{SW}}$ & - & 0.03 & 0.03 & Slater (1980) \\
\hline Drag bottom coefficient & $\mathrm{C} 1$ & - & 0.001 & $0.001-0.003$ & Wüest and Lorke (2003) \\
\hline Horizontal diffusivity & $\kappa$ & $\mathrm{m}^{2} \mathrm{~s}^{-1}$ & 5.25 & 5.25 & Pacheco et al. (2011) \\
\hline $\begin{array}{l}\text { Fraction of incident shortwave in near } \\
\text { infrared region }\end{array}$ & fNIR & - & 0.51 & - & ELCOM default \\
\hline $\begin{array}{l}\text { Fraction of incident shortwave in } \\
\text { photosynthetically active region }\end{array}$ & fPAR & - & 0.45 & 0.446 & ELCOM default \\
\hline $\begin{array}{l}\text { Fraction of incident shortwave in } \\
\text { ultraviolet-a region }\end{array}$ & fUVA & - & 0.035 & - & ELCOM default \\
\hline $\begin{array}{l}\text { Fraction of incident shortwave in } \\
\text { ultraviolet-b region }\end{array}$ & fUVB & - & 0.005 & - & ELCOM default \\
\hline Extinction coefficient for near infrared region & KdNIR & $\mathrm{m}^{-1}$ & 2 & - & ELCOM default \\
\hline $\begin{array}{l}\text { Extinction coefficient for photosynthetically } \\
\text { active region }\end{array}$ & KdPAR & $\mathrm{m}^{-1}$ & 1.2 & $0.49-4.03$ & Measured in situ using TriOS® Ramses radiometers \\
\hline Extinction coefficient for ultraviolet-a region & KdUVA & $m^{-1}$ & 1 & - & ELCOM default \\
\hline Extinction coefficient for ultraviolet-b region & KdUVB & $m^{-1}$ & 2.5 & - & ELCOM default \\
\hline \multicolumn{6}{|l|}{ b) Biological parameters } \\
\hline Average ratio of carbon to chlorophyll- $a$ & Ycc & $\begin{array}{l}\operatorname{mg~C~mg~} \\
\text { Chl- } a^{-1}\end{array}$ & 40 & 40 & Deus et al. (2013); Robson and Hamilton (2004) \\
\hline Constant settling velocity & ws & $\mathrm{m} \mathrm{s}^{-1}$ & $1 \times 10^{-5}$ & $1 \times 10^{-5}$ & Gal et al. (2009) \\
\hline Critical shear stress & tсpy & $\mathrm{N} \mathrm{m}^{-2}$ & 0.001 & 0.001 & Robson and Hamilton (2004) \\
\hline Diameter of phytoplankton & dia & $\mathrm{m}$ & $\begin{array}{l}0.4 \times \\
10^{-4}\end{array}$ & $0.00005-0.0004$ & Wallace et al., 2000 \\
\hline $\begin{array}{l}\text { Fraction of respiration relative to total } \\
\text { metabolic loss rate }\end{array}$ & FRML & - & 0.5 & $0.25-0.7$ & Robson and Hamilton (2004); Gal et al. (2009) \\
\hline Half saturation constant for nitrogen & KN & $\mathrm{mg} \mathrm{L}^{-1}$ & 0.047 & $0.014-0.081$ & $\begin{array}{l}\text { Robson and Hamilton (2004); Gal et al. (2009); Deus et al., } \\
2013\end{array}$ \\
\hline Half saturation constant for phosphorus & KP & $\mathrm{mg} \mathrm{L}^{-1}$ & 0.035 & $0.001-0.006$ & $\begin{array}{l}\text { Robson and Hamilton (2004); Gal et al. (2009); Deus et al., } \\
2013\end{array}$ \\
\hline Maximum internal nitrogen concentration & INmax & $\begin{array}{l}\mathrm{mg} \mathrm{N} \text { mg } \\
\mathrm{Chl}-a^{-1}\end{array}$ & 5 & 5 & Gal et al. (2009) \\
\hline $\begin{array}{l}\text { Maximum internal phosphorus } \\
\text { concentration }\end{array}$ & IPmax & $\begin{array}{l}\mathrm{mg} P \mathrm{mg} \\
\mathrm{Chl}-a^{-1}\end{array}$ & 0.8 & 0.8 & Gal et al. (2009) \\
\hline $\begin{array}{l}\text { Maximum rate of phytoplankton nitrogen } \\
\text { uptake }\end{array}$ & UNmax & 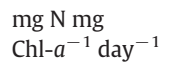 & 1.5 & 1.5 & Gal et al. (2009) \\
\hline $\begin{array}{l}\text { Maximum rate of phytoplankton phosphorus } \\
\text { uptake }\end{array}$ & UPmax & 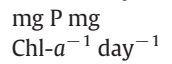 & 0.2 & 0.2 & Robson and Hamilton (2004) \\
\hline $\begin{array}{l}\text { Maximum potential growth rate of } \\
\text { phytoplankton }\end{array}$ & Pmax & Day $^{-1}$ & 1.4 & $0.7-2$ & $\begin{array}{l}\text { Robson and Hamilton (2004); Gal et al. (2009); Deus et al., } \\
2013\end{array}$ \\
\hline Minimum internal nitrogen concentration & INmin & $\begin{array}{l}\mathrm{mg} \mathrm{N} \mathrm{mg} \\
\mathrm{Chl}-a^{-1}\end{array}$ & 2.5 & 2.5 & Gal et al. (2009) \\
\hline $\begin{array}{l}\text { Minimum internal phosphorus } \\
\text { concentration }\end{array}$ & IPmin & $\begin{array}{l}\text { mg P mg } \\
\text { Chl- } a^{-1}\end{array}$ & 0.4 & 0.4 & Gal et al. (2009) \\
\hline Phytoplankton respiration function & krp & - & 0.01 & 0.01 & Gal et al. (2009) \\
\hline $\begin{array}{l}\text { Respiration/mortality/excretion rate } \\
\text { coefficient }\end{array}$ & $\mathrm{kr}$ & Day $^{-1}$ & 0.08 & $0.0175-0.08$ & $\begin{array}{l}\text { Robson and Hamilton (2004); Gal et al. (2009); Deus et al., } \\
2013\end{array}$ \\
\hline Temperature multiplier for phytoplankton & $\mathrm{vT}$ & - & 1.075 & $1.07-1.08$ & Robson and Hamilton (2004); Gal et al. (2009) \\
\hline Temperature multiplier for respiration & $\mathrm{vR}$ & - & 1.065 & $1.05-1.08$ & Robson and Hamilton (2004); Gal et al. (2009) \\
\hline \multicolumn{6}{|l|}{ c) Chemical parameters } \\
\hline Critical shear stress for resuspension & $\mathrm{tcPOM}$ & $\mathrm{N} \mathrm{m}^{-2}$ & 0.02 & 0.05 & Robson and Hamilton (2004) \\
\hline Denitrification rate coefficient & koN2 & Day $^{-1}$ & 0.08 & $0.08-0.4$ & $\begin{array}{l}\text { Robson and Hamilton (2004); Bruce et al. (2006); Gal et al. } \\
\text { (2009); Missaghi and Hondzo (2010) }\end{array}$ \\
\hline $\begin{array}{l}\text { Density of particulate organic matter } \\
\text { particles }\end{array}$ & POMDensity & $\mathrm{kg} \mathrm{m}^{-3}$ & 1050 & $1030-1080$ & $\begin{array}{l}\text { Bruce et al. (2006); Gal et al. (2009); Missaghi and Hondzo } \\
\text { (2010) }\end{array}$ \\
\hline $\begin{array}{l}\text { Diameter of particulate organic matter } \\
\text { particles }\end{array}$ & POMDiameter & $\mathrm{m}$ & $1 \times 10^{-5}$ & $\begin{array}{l}0.5 \times 10^{-5}- \\
1.5 \times 10^{-5}\end{array}$ & $\begin{array}{l}\text { Bruce et al. (2006); Gal et al. (2009); Missaghi and Hondzo } \\
\text { (2010) }\end{array}$ \\
\hline Half-saturation constant for nitrification & KOn & $\mathrm{mg} \mathrm{O} \mathrm{L}{ }^{-1}$ & 2 & $0.5-4$ & $\begin{array}{l}\text { Robson and Hamilton (2004); Bruce et al. (2006); Gal et al. } \\
\text { (2009); Missaghi and Hondzo (2010) }\end{array}$ \\
\hline Half-saturation constant for denitrification & KN2 & $\mathrm{mg} \mathrm{L}^{-1}$ & 0.4 & $0.3-0.5$ & $\begin{array}{l}\text { Robson and Hamilton (2004); Bruce et al. (2006); Gal et al. } \\
\text { (2009); Missaghi and Hondzo (2010) }\end{array}$ \\
\hline Maximum mineralization of DON to $\mathrm{NH}_{4}$ & DON1max & Day $^{-1}$ & 0.04 & $0.01-0.08$ & Robson and Hamilton (2004); Missaghi and Hondzo (2010) \\
\hline Maximum mineralization of DOC to DIC & Doc1max & Day $^{-1}$ & 0.011 & $0.011-0.07$ & $\begin{array}{l}\text { Robson and Hamilton (2004); Bruce et al. (2006); Missaghi } \\
\text { and Hondzo (2010) }\end{array}$ \\
\hline $\begin{array}{l}\text { Maximum mineralization of DOP } \\
\text { to } \mathrm{PO}_{4}\end{array}$ & DOP1max & Day $^{-1}$ & 0.25 & 0.25 & Missaghi and Hondzo (2010) \\
\hline Maximum transfer of PON to DON & PON1max & Day $^{-1}$ & 0.05 & 0.005 & Gal et al. (2009); Missaghi and Hondzo (2010) \\
\hline Maximum transfer of POC to DOC & POC1max & Day $^{-1}$ & 0.05 & $0.001-0.07$ & $\begin{array}{l}\text { Bruce et al. (2006); Gal et al. (2009); Missaghi and Hondzo } \\
\text { (2010) }\end{array}$ \\
\hline Maximum transfer of POP to DOP & POP1max & Day $^{-1}$ & 0.03 & 0.03 & Gal et al. (2009); Missaghi and Hondzo (2010) \\
\hline Nitrification rate coefficient & koNH & Day $^{-1}$ & 0.1 & $0.03-0.25$ & $\begin{array}{l}\text { Robson and Hamilton (2004); Bruce et al. (2006); Gal et al. } \\
\text { (2009); Missaghi and Hondzo (2010) }\end{array}$ \\
\hline
\end{tabular}


Table 3 (continued)

\begin{tabular}{|c|c|c|c|c|c|}
\hline & Symbol & Units & $\begin{array}{l}\text { Assigned } \\
\text { value }\end{array}$ & $\begin{array}{l}\text { Values from } \\
\text { field/literature }\end{array}$ & Source \\
\hline Photo-respiration phytoplankton DO loss & prc & - & 0.02 & 0.02 & Missaghi and Hondzo (2010) \\
\hline $\begin{array}{l}\text { Respiration stoichiometric ratio of carbon to } \\
\text { oxygen }\end{array}$ & YOC & $\mathrm{mg} \mathrm{C} \mathrm{mg} \mathrm{O}^{-1}$ & 2.66667 & 2.66667 & $\begin{array}{l}\text { Robson and Hamilton (2004); Bruce et al. (2006); Gal et al. } \\
\text { (2009) }\end{array}$ \\
\hline Specific attenuation coefficient of POC & KePOC & $\mathrm{m}^{2} \mathrm{~g}^{-1}$ & 0.02 & 0.02 & Missaghi and Hondzo (2010) \\
\hline Specific attenuation coefficient of DOC & KeDOC & $\mathrm{m}^{2} \mathrm{~g}^{-1}$ & 0.001 & 0.001 & Bruce et al. (2006); Gal et al. (2009) \\
\hline Temperature multiplier for denitrification & vN2 & - & 1.06 & $1.045-1.08$ & $\begin{array}{l}\text { Robson and Hamilton (2004); Bruce et al. (2006); Gal et al. } \\
\text { (2009) }\end{array}$ \\
\hline Temperature multiplier for nitrification & vON & - & 1.08 & 1.08 & $\begin{array}{l}\text { Robson and Hamilton (2004); Bruce et al. (2006); Gal et al. } \\
\text { (2009) }\end{array}$ \\
\hline \multicolumn{6}{|l|}{ d) Sediment related parameters } \\
\hline Controls sediment release of $\mathrm{PO}_{4}$ via oxygen & $\mathrm{KOxS}-\mathrm{PO}_{4}$ & $\mathrm{~g} \mathrm{~m}^{-3}$ & 0.5 & $0.05-1$ & $\begin{array}{l}\text { Robson and Hamilton (2004); Bruce et al. (2006); Gal et al. } \\
\text { (2009); Missaghi and Hondzo (2010) }\end{array}$ \\
\hline Fraction of sediment that is organics & SedOrganicFrac & - & 0.16 & $0.04-0.36$ & BALCAR project database \\
\hline $\begin{array}{l}\text { Half-saturation constant for DO sediment } \\
\text { flux }\end{array}$ & KSOs & $\mathrm{mg} \mathrm{O} \mathrm{L}{ }^{-1}$ & 3 & $0.5-3.2$ & $\begin{array}{l}\text { Robson and Hamilton (2004); Bruce et al. (2006); Gal et al. } \\
\text { (2009); Missaghi and Hondzo (2010) }\end{array}$ \\
\hline $\begin{array}{l}\text { Half-saturation constant for sediment DOC } \\
\text { release dependence on DO }\end{array}$ & KDOS-doc & $\mathrm{g} \mathrm{m}^{-3}$ & 0.5 & $0.005-0.5$ & Gal et al. (2009); Missaghi and Hondzo (2010) \\
\hline $\begin{array}{l}\text { Half-saturation constant for sediment DON } \\
\text { release dependence on DO }\end{array}$ & KDOS-don & $\mathrm{g} \mathrm{m}^{-3}$ & 0.5 & $0.005-0.5$ & Gal et al. (2009); Missaghi and Hondzo (2010) \\
\hline $\begin{array}{l}\text { Half-saturation constant for sediment DOP } \\
\text { release dependence on DO }\end{array}$ & KDOS-dop & $\mathrm{g} \mathrm{m}^{-3}$ & 0.5 & $0.005-0.5$ & Gal et al. (2009); Missaghi and Hondzo (2010) \\
\hline $\begin{array}{l}\text { Half-saturation constant for sediment } \mathrm{NH}_{4} \\
\text { release dependence on DO }\end{array}$ & KDOS-NH4 & $\mathrm{g} \mathrm{m}^{-3}$ & 0.5 & $0.05-1$ & $\begin{array}{l}\text { Robson and Hamilton (2004); Bruce et al. (2006); Gal et al. } \\
\text { (2009); Missaghi and Hondzo (2010) }\end{array}$ \\
\hline $\begin{array}{l}\text { Half-saturation constant for sediment } \mathrm{NO}_{3} \\
\text { release dependence on DO }\end{array}$ & KDOS-NO3 & $\mathrm{g} \mathrm{m}^{-3}$ & 0.03 & $0.03-0.5$ & Gal et al. (2009); Missaghi and Hondzo (2010) \\
\hline Release rate of DON & SmpdonL & $\mathrm{g} \mathrm{m}^{-2}$ day $^{-1}$ & 0.02 & $0-0.02$ & Robson and Hamilton (2004); Hipsey et al. (2014) \\
\hline Release rate of DOP & SmpdopL & $\mathrm{g} \mathrm{m}^{-2}$ day $^{-1}$ & 0.004 & $0-0.004$ & Robson and Hamilton (2004); Hipsey et al. (2014) \\
\hline Maximum $\mathrm{NH}_{4}$ sediment flux & SmpNH4 & $\mathrm{g} \mathrm{m}^{-2}$ day $^{-1}$ & 0.05 & $0.05-0.09$ & $\begin{array}{l}\text { Bruce et al. (2006); Gal et al. (2009); Missaghi and Hondzo } \\
\text { (2010) }\end{array}$ \\
\hline Maximum release rate of DOC at $20^{\circ} \mathrm{C}$ & SmpdocL & $\mathrm{g} \mathrm{m}^{-2}$ day $^{-1}$ & 0.005 & 0.005 & Gal et al. (2009); Missaghi and Hondzo (2010) \\
\hline Maximum release rate of $\mathrm{NO}_{3}$ at $20^{\circ} \mathrm{C}$ & SmpNO3 & $\mathrm{g} \mathrm{m}^{-2}$ day $^{-1}$ & 0.03 & 0.03 & Gal et al. (2009); Missaghi and Hondzo (2010) \\
\hline Maximum release rate of $\mathrm{PO}_{4}$ at $20^{\circ} \mathrm{C}$ & SmpPO4 & $\mathrm{g} \mathrm{m}^{-2}$ day $^{-1}$ & 0.001 & $0.0008-0.04$ & $\begin{array}{l}\text { Bruce et al. (2006); Gal et al. (2009); Missaghi and Hondzo } \\
\text { (2010) }\end{array}$ \\
\hline Static sediment exchange rate & rSOs & $\mathrm{g} \mathrm{m}^{-2}$ day $^{-1}$ & 1 & $0.9-6$ & $\begin{array}{l}\text { Robson and Hamilton (2004); Bruce et al. (2006); Gal et al. } \\
\text { (2009); Missaghi and Hondzo (2010) }\end{array}$ \\
\hline Temperature multiplier of sediment fluxes & $\theta($ sed $)$ & - & 1.065 & $1.05-1.08$ & $\begin{array}{l}\text { Robson and Hamilton (2004); Bruce et al. (2006); Gal et al. } \\
\text { (2009); Missaghi and Hondzo (2010) }\end{array}$ \\
\hline
\end{tabular}

Balcar project and simulated in our study presents a similar behavior, since these are key factors controlling the carbon input and emissions in lakes and reservoirs (Tranvik et al., 2009). For the water level, we compared the time series simulated by the ELCD model at the dam with the time series provided by the Eletronorte. All comparisons were made for the two periods of simulation (summer/wet and winter/dry) using three well-accepted goodness-of-fit measures: coefficient of determination from linear regression $\left(R^{2}\right)$, RMSE, and the Normalized RMSE (NRMSE).

\subsection{Correlation analysis among $\mathrm{CO}_{2}$ flux and predictive variables}

This analysis aimed to identify the main meteorological forcing and physical process/es occurring in the water column and govern the $\mathrm{CO}_{2}$ flux in the Tucuruí reservoir. The influence of meteorological forcing was assessed by correlation analysis among simulated values of $\mathrm{F}_{\mathrm{CO} 2}$ and the meteorological variables collected by the SIMA: (1) air temperature $\left(T_{a},{ }^{\circ} \mathrm{C}\right)$; (2) relative humidity $\left(R_{h}, \%\right) ;(3)$ atmospheric pressure $\left(P_{a t m}, \mathrm{hPa}\right) ;(4)$ wind speed $\left(u_{10}, \mathrm{~m} \mathrm{~s}^{-1}\right)$; and (5) incident shortwave radiation $\left(S W, \mathrm{~W} \mathrm{~m}^{-2}\right)$.

The influence of physical and biological processes on the diffusive $\mathrm{CO}_{2}$ flux was assessed using time series derived from the results of the simulations with ELCD model. Selected for this analysis were: (1) concentration of chlorophyll- $a$ ([Chl- $\left.a], \mu \mathrm{g} \mathrm{L}{ }^{-1}\right)$; (2) concentration of DIC ([DIC], mg L $\left.{ }^{-1}\right)$; (3) water temperature $\left(T_{w},{ }^{\circ} \mathrm{C}\right)$; (4) retention time ( $R T$, day); (5) speed of gas exchange $\left(k_{\mathrm{CO} 2}, \mathrm{~m} \mathrm{~s}^{-1}\right) ;(6)$ latent heat flux $\left(E, \mathrm{~W} \mathrm{~m}^{-2}\right)$; (7) sensible heat flux $\left(H, \mathrm{~W} \mathrm{~m}^{-2}\right)$; (8) long wave flux $\left(Q_{L W}, W \mathrm{~m}^{-2}\right)$; (9) partial pressure of $\mathrm{CO}_{2}$ in the water surface $\left(p_{\mathrm{CO} 2}, \mu \mathrm{atm}\right) ;(10)$ convective entrainment velocity ( $w^{*}$, $\left.\mathrm{m} \mathrm{s}^{-1}\right)$; (11) turbulent kinetic energy introduced into the mixed layer $\left(F q, \mathrm{~m}^{3} \mathrm{~s}^{-3}\right)$; (12) wind shear velocity at the water surface $\left(u_{w}{ }^{*}\right.$, $\mathrm{m} \mathrm{s}^{-1}$ ); and (13) the depth of the surface mixed layer $(h, \mathrm{~m})$.

All 18 variables used in this analysis were pre-selected based on previous studies that have investigated and listed possible factors that may impact the $\mathrm{CO}_{2}$ flux in lake and reservoirs (e.g., St Louis et al. 2000; Eugster et al., 2003; Barros et al., 2011; Polsenaere et al., 2013; Pacheco et al., 2015).

\subsection{Global estimation}

The surface averaged $F_{\mathrm{CO} 2}$ time series, converted and aggregate to units of $\mathrm{mg} \mathrm{C} \mathrm{m}{ }^{-2}$ day $^{-1}$, were used to compute the total diffusive $\mathrm{CO}_{2}$ emission by THR along the 2013 year (in units of $\mathrm{Tg} C$ year $^{-1}$ ). As the surface area of THR shows a great variability along the year, going from around $1500 \mathrm{~km}^{2}$ to around $2500 \mathrm{~km}^{2}$, we considered the surface area variation in our estimative of total diffusive $\mathrm{CO}_{2}$ emission for 2013 year. The water level-area relation proposed by Curtarelli et al. (2015b) and daily water level data simulated by ELCD model were used to compute the surface area time series for 2013 year. The daily emission, in units of $\mathrm{Tg} \mathrm{C}_{\text {day }}{ }^{-1}$, was obtained by multiplying the reservoir area $\left(\mathrm{m}^{2}\right)$ by $F_{\mathrm{CO} 2}\left(\mathrm{mg} \mathrm{C} \mathrm{m}^{-2}\right.$ day $\left.^{-1}\right)$ for each day of year. The total diffusive $\mathrm{CO}_{2}$ emission for 2013 year, in units of $\mathrm{Tg}^{\mathrm{C}}$ year ${ }^{-1}$, was obtained by the sum of daily emission values. The result of this analysis was compared to previous estimates available in the literature (e.g. Fearnside (1995); Santos et al. (2006) and Brazil/MME (2014)), based on a fix emission rate and reservoir surface area. 


\section{Results}

\subsection{Environmental conditions during summer/wet and winter/dry periods}

A marked diel pattern was observed in all meteorological variables monitored by SIMA during the summer/wet and winter/dry periods (Fig. 2a-1). Statistical $t$-test showed that among all the meteorological variables only the wind speed and direction presented no significant differences between the seasons $(p>0.01)$. On the other hand air temperature, relative humidity, atmospheric pressure and incident shortwave radiation showed significant differences between the seasons $(p<0.01)$.

Air temperature (Fig. 2a and b) ranged, on average, from $25.3^{\circ} \mathrm{C}$ to $29.0^{\circ} \mathrm{C}$ along the days in the summer period, with a daily mean of $26.9{ }^{\circ} \mathrm{C}$. For the winter period, air temperature ranged from $25.5^{\circ} \mathrm{C}$ to $29.8^{\circ} \mathrm{C}$, with daily mean of $27.6^{\circ} \mathrm{C}$. The highest air temperature was observed at approximately 17:00 h local time (LT $=-3 \mathrm{GMT}$ ), and the lowest temperature was observed at approximately 07:00 h LT during the summer/wet season. A small shift was observed in this pattern during the winter/dry period with the maximum air temperature occurring at 19:00 $\mathrm{h} \mathrm{LT}$ and minimum at 08:00 h LT. Consistent with the pattern of the diel variations in the air temperature, the maximum relative humidity was observed at approximately 06:00 $\mathrm{h}$ LT, while the minimum relative humidity was observed at approximately 16:00 h LT during the summer/wet season (Fig. 2c). For the winter/ dry season (Fig. 2d) the maximum relative humidity was observed at approximately 07:00 $\mathrm{h} \mathrm{LT}$ while the minimum relative humidity was observed at approximately 19:00 h LT. The average values for the minimum and maximum relative humidity were $70 \%$ and $84 \%$, respectively, for the summer/wet period and $60 \%$ and $79 \%$, respectively, for the winter period/dry.

The atmospheric pressure (Fig. 2e) fluctuated between $996 \mathrm{hPa}$ and $1000 \mathrm{hPa}$, on average, throughout the days in the summer period. In this season, the highest atmospheric pressure value was observed at 10:00 h $\mathrm{LT}$, and the lowest was observed at 17:00 $\mathrm{h} \mathrm{LT}$. During the winter period (Fig. 2f) the atmospheric pressure ranged between $998 \mathrm{hPa}$ and $1001 \mathrm{hPa}$ with the minimum occurring at 20:00 $\mathrm{h} \mathrm{LT}$ and maximum at 12:00 h LT. On the synoptic scale, no sign of frontal passages, which are associated with a significant pressure rise (ahead of the front) and drop (behind the front), were observed in the dataset for both seasons. However it was expected considering the low latitude of the THR.

The peak of incident shortwave radiation was frequently shifted from its normal time at noon to approximately 13:00 h LT during the summer/wet (Fig. $2 \mathrm{~g}$ ) while during the winter/dry (Fig. 2h) season the peak occurred generally at noon time. The average daily maximum shortwave radiation value was $643 \mathrm{~W} \mathrm{~m}^{-2}$ during the summer and $865 \mathrm{~W} \mathrm{~m}^{-2}$ during the winter. However, in cloudless conditions, the peak incident shortwave radiation can be higher than $1100 \mathrm{~W} \mathrm{~m}^{-2}$ in both seasons. On average, in the study region, the sunrise and sunset occur approximately 06:00 h LT and 18:00 h LT, respectively; thus, approximately $12 \mathrm{~h}$ of the incident shortwave radiation are available in both seasons.

The wind speed (Fig. 2i and j) ranged from $1.8 \mathrm{~m} \mathrm{~s}^{-1}$ to $3.2 \mathrm{~m} \mathrm{~s}^{-1}$, with a daily mean value of $2.5 \mathrm{~m} \mathrm{~s}^{-1}$ in both seasons. The diel variation of wind speed exhibited a similar pattern in both seasons, which was opposite to that of the air temperature, with the maximum wind speed occurring generally during the night and morning period (between 3:00 $\mathrm{h} \mathrm{LT}$ and 10:00 $\mathrm{h} \mathrm{LT}$ ) and the minimum occurring during the afternoon (between 14:00 h LT and 16:00 h LT). In both seasons the wind usually flowed from southeast to northwest (Fig. 2k and 1) along the main axis of the reservoir.

The rainfall, and cloud cover over the THR were higher during the summer/wet (Fig. $2 \mathrm{~m}$ and o) period when compared with the winter/ dry (Fig. $2 \mathrm{n}$ and $\mathrm{p}$ ) season. The accumulated rainfall during the summer/wet was $1160 \mathrm{~mm}$ while during the winter/dry was $156 \mathrm{~mm}$. The high rainfall and cloud cover observed during the summer/wet period can be associated with the Intertropical Convergence Zone (ITCZ) dynamics along the year and the occurrence of mesoscale convective systems, which is more frequent during this time of year over tropical South America (Horel et al., 1989).

The inflow and outflow (Fig. $2 \mathrm{q}$ and r) showed a distinct pattern between the two analyzed periods which showed a high inflow in the end of the summer period $\left(\sim 20,000 \mathrm{~m}^{3} \mathrm{~s}^{-1}\right)$. The average Tocantins River inflow was around 4-folds higher during the summer $\left(13,000 \mathrm{~m}^{3} \mathrm{~s}^{-1}\right)$ than during the winter $\left(3000 \mathrm{~m}^{3} \mathrm{~s}^{-1}\right)$. High inflow values compared to the outflow where observed during most of the summer/wet season resulting in the rise of water level; for 2013 year the reservoir reached the maximum operational level (i.e. $74 \mathrm{~m}$ above mean sea level) at the end of wet season (March-April). On the other hand, during the winter/dry season the outflow exceeded the inflow and hence the water level decreased along the period, reaching near $67 \mathrm{~m}$. Some water quality parameters measured at Tocantins River, such as water temperature, $\mathrm{pH}$ and $\mathrm{OD}$, exhibited similar values for both seasons (Fig. 3). With exception of the DIC, the C inputs concentrations were higher during the summer compared to winter period; the total phosphorous and ammonium load were also higher during the summer period.

The models results showed that during the summer/wet period the reservoir exhibited weak water column stratification, with $<1{ }^{\circ} \mathrm{C}$ of difference between the surface and bottom. This difference increased to $2.5{ }^{\circ} \mathrm{C}$ during the winter/dry period. The Chl- $a$ concentration was higher during the summer/wet, presenting values near $70 \mathrm{\mu g} \mathrm{L}^{-1}$ in the transition zone and main channel of the reservoir. The DIC concentration showed an opposite behavior compared to chlorophyll- $a$, with

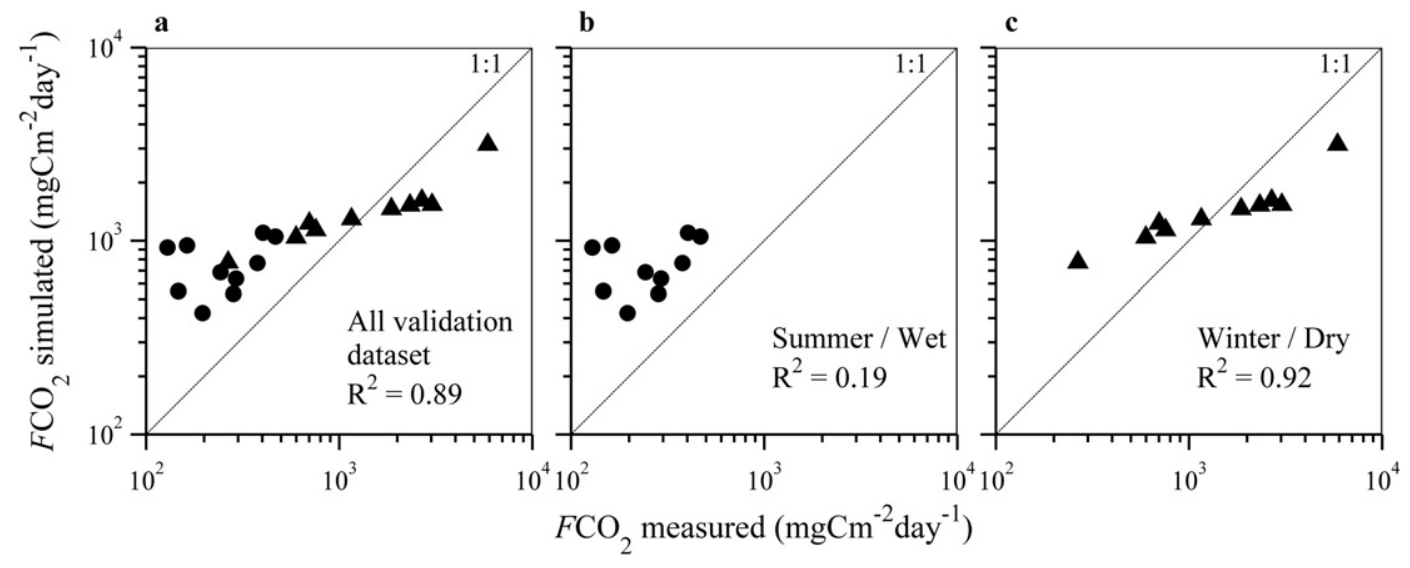

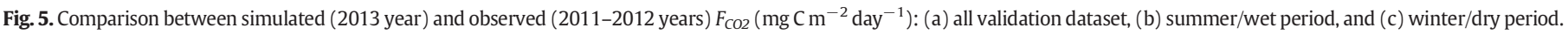




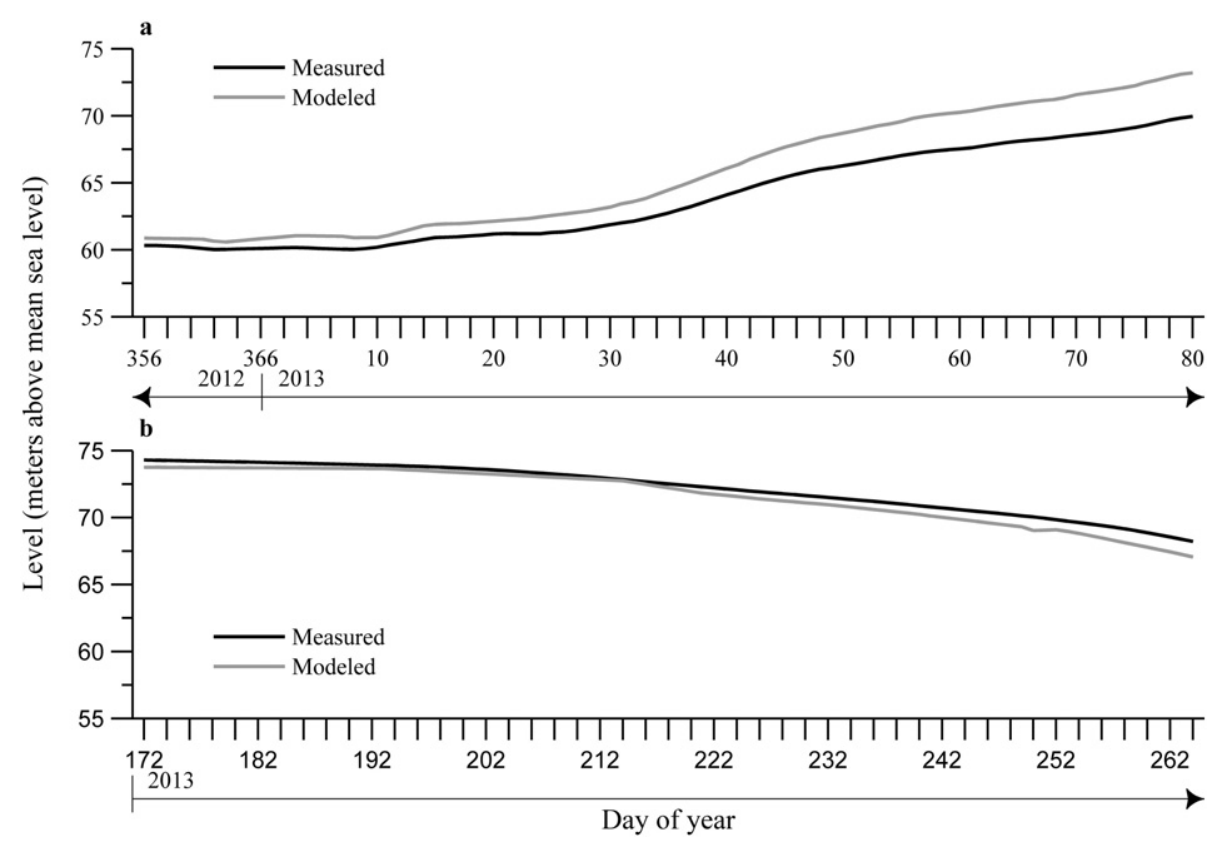

Fig. 6. Comparison between simulated and measured water level at the dam: (a) summer/wet period, and (b) winter/dry period.

higher values during the winter/dry period (near $8 \mathrm{mg} \mathrm{L}^{-1}$ in the bottom of reservoir). In the supplementary material we provided two videos showing the results of ELCD model simulations for the A-A' transect (see Fig. 1 for location), one for the summer/wet period and other for the winter/dry period.

\subsection{Model validation and source of errors}

Fig. 5 shows the comparison between the simulated (this study, 2013 year) and observed (Eletronorte data provided in the Balcar project database, 2011-2012 year) $F_{\mathrm{CO} 2}$ at different sampling sites and seasons. Analyzing all the validation dataset (Fig. 5a), the simulated $F_{\mathrm{CO} 2}$ values showed good agreement with the measured values along the Balcar project $\left(R^{2}=0.89, n=20, p<0.01\right)$ and, in average, the model overestimated the simulated $F_{\mathrm{CO} 2}$ (bias $=20 \mathrm{mg} \mathrm{C} \mathrm{m}^{-2}$ day $^{-1}$ ).
The mean measured $F_{\mathrm{CO} 2}$ was $-1098 \mathrm{mg} \mathrm{C} \mathrm{m}^{-2}$ day $^{-1}$ while the mean simulated $F_{\mathrm{CO} 2}$ was $-1119 \mathrm{mg} \mathrm{C} \mathrm{m}^{-2}$ day $^{-1}$, around $2 \%$ difference.

Analyzing the simulated periods separately, we can see that during the summer/wet period (Fig. 5b), the model simulation showed poor correlation with the observed data $\left(R^{2}=0.19, n=10\right.$, $p<0.01$ ) and a consistent pattern in overestimation of the $F_{\mathrm{CO} 2}$ by around $400 \mathrm{mg} \mathrm{C} \mathrm{m}^{-2}$ day $^{-1}$. The mean observed $F_{\mathrm{CO} 2}$ was $-300 \mathrm{mg} \mathrm{C} \mathrm{m}{ }^{-2}$ day $^{-1}$ while the mean simulated $F_{\mathrm{CO} 2}$ was $-700 \mathrm{mg} \mathrm{C} \mathrm{m}^{-2}$ day $^{-1}$. This poor correlation can be partially explained due to the fact that during the summer/wet season the $F_{\mathrm{CO} 2}$ presents high spatial and temporal variability in Tucuruí reservoir (see Sections 4.3 and 4.4 ) and the grid size used during the model simulation $\left(400 \times 400 \mathrm{~m}=160.000 \mathrm{~m}^{2}\right)$ is much higher than the footprint of the floating chambers used to measure the $F_{\mathrm{CO} 2}$ in situ.

During the winter/dry period (Fig. 5c), the model simulation showed a good correlation with the observed data $\left(R^{2}=0.92, n=10, p<0.01\right)$

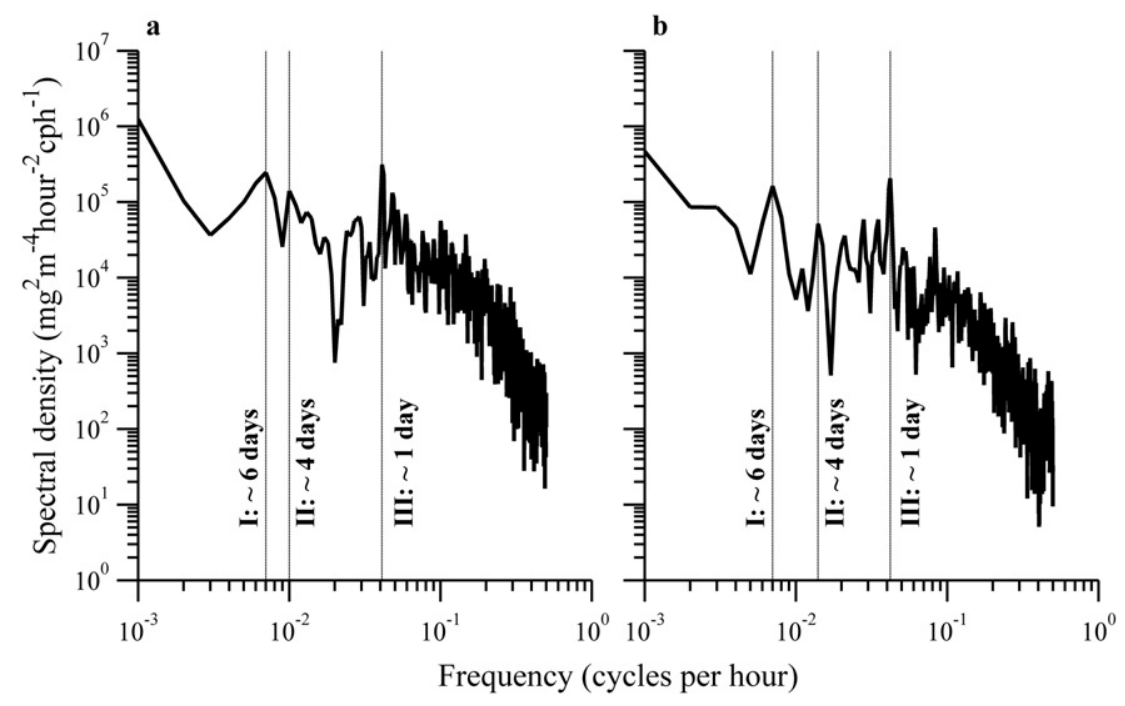

Fig. 7. Power spectra density analysis: (a) summer/wet period, and (b) winter/dry period. 


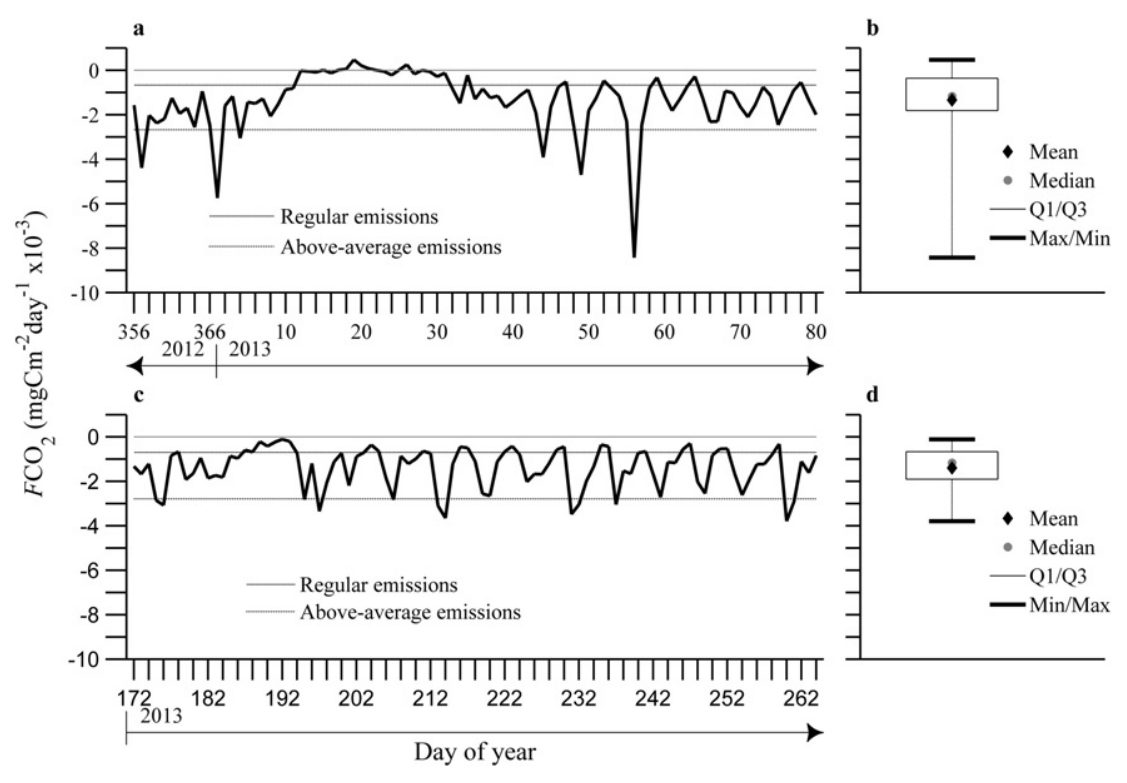

Fig. 8. Daily integrated surface averaged $F_{\mathrm{CO} 2}\left(\mathrm{mg} \mathrm{C} \mathrm{m}^{-2}\right.$ day $\left.{ }^{-1}\right)$ : (a-b) summer/wet period, (c-d) winter/dry period.

and a tendency to underestimate $F_{\mathrm{CO} 2}$ values higher than $1000 \mathrm{mg} \mathrm{C} \mathrm{m}^{-2}$ day $^{-1}$. The bias between observed and simulated $F_{\mathrm{CO} 2}$ values was $-450 \mathrm{mg} \mathrm{C} \mathrm{m}{ }^{-2}$ day $^{-1}$. The mean measured $F_{\mathrm{CO} 2}$ was $-1926 \mathrm{mg} \mathrm{C} \mathrm{m}^{-2}$ day $^{-1}$ while the mean simulated $F_{\mathrm{CO} 2}$ was $-1476 \mathrm{mg} \mathrm{C} \mathrm{m}^{-2}$ day $^{-1}$.

Fig. 6 shows the comparison between measured and simulated water level at dam, for each of the periods analyzed. For the summer period the model showed a slight tendency to underestimate the water level in the reservoir (Fig. 6a). The bias for the simulated water level was $1.8 \mathrm{~m}$ and RMSE was $2 \mathrm{~m}$ (NRMSE $=16 \%$ of the range). For the winter/wet period, the model presented an opposite behavior to that seen in the summer, with a slight tendency to overestimate the water level (Fig. 6b). The bias of the simulated water level was $0.52 \mathrm{~m}$ and the RMSE was $0.6 \mathrm{~m}$ (NRMSE $=9 \%$ of the range).

The differences observed between the measured and simulated water level for the summer season can be explained by the fact that during the simulations it was not considered the water inlets for smaller tributaries (e.g., the Pucuruí river, Caraipé river, Lontra river, Bacurí river, Jacundá river and Repartimento river). With respect to contributions from smaller tributaries during the summer period, it was found that these can be as high as $300 \mathrm{~m}^{3} \mathrm{~s}^{-1}$ (unpublished data collected by the UFRJ team in 10 smaller tributaries available in the project database Balcar). For an average surface area of $2000 \mathrm{~km}^{2}$ this volume of water corresponds to a water depth of $1.2 \mathrm{~m}$ ( $67 \%$ of the resulting bias). The minor errors found during the simulation of the winter period can be primarily attributed to the fact that the flow of the smaller tributaries decrease over the year resulting in the reduction of their influence over the water balance $\left(\sim 100 \mathrm{~m}^{3} \mathrm{~s}-1\right.$, unpublished data collected by the UFRJ team in five smaller tributaries available on the project database Balcar).

Other sources of error which are worth to be highlighted for possible improvements in future works are: (1) the simplification of phytoplankton and zooplankton communities of Tucuruí reservoir, considering only one algae group (cyanobacteria) and none zooplankton group during the model simulations; (2) the miss representation of the spatial variability of meteorological variables over the reservoir surface, using only the SIMA data to force the model; and (3) the miss representation of reservoir bathymetry in some embayment, due to the lack of data during the grid discretization (see Curtarelli et al., 2015b), which can lead to unreliable estimates in these areas.

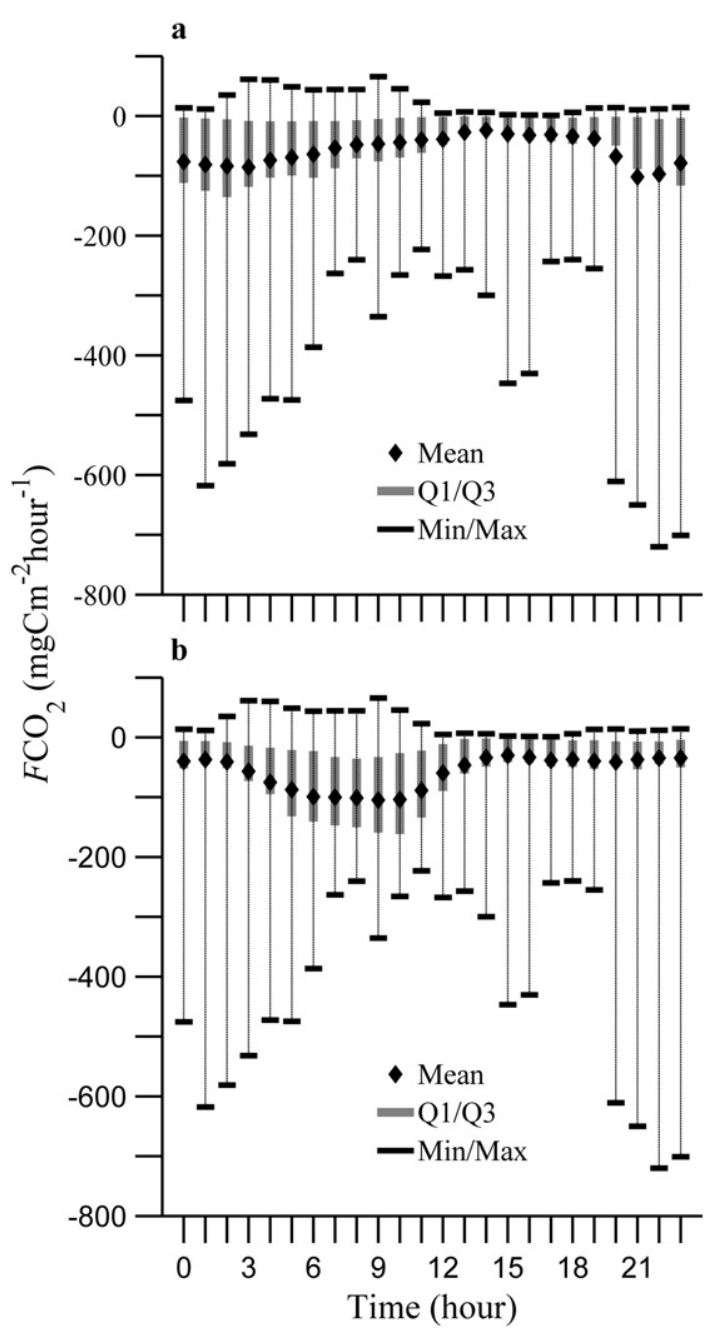

Fig. 9. Mean diel variability of surface averaged $F_{\mathrm{CO} 2}\left(\mathrm{mg} \mathrm{C} \mathrm{m}^{-2} \mathrm{~h}^{-1}\right)$ : (a) summer/wet period, and (b) winter/dry period. 


\subsection{Temporal variability of $\mathrm{CO}_{2}$ flux}

To assess the temporal variability of $F_{\mathrm{CO} 2}$ during the summer/wet and winter/dry periods we performed a power spectral density (PSD) analysis in the hourly time series of surface averaged $F_{\mathrm{CO} 2}$ (Fig. 7). The PSD analysis was performed using MatLab ${ }^{\circledR}$ program and the onesided PSD function which contains the total signal power in half the Nyquist frequency. This analysis allowed identifying three well defined peaks, with different magnitude and frequencies, which indicate a high temporal variability within the seasons. The period of peaks was similar in both seasons analyzed: (I) 6 days $\left(7 \times 10^{-3}\right.$ cycles per hour $\left.(\mathrm{cph})\right)$, (II) 4 days $\left(1 \times 10^{-2} \mathrm{cph}\right)$ and (III) 1 day $\left(3 \times 10^{-2} \mathrm{cph}\right)$.

Fig. 8 shows the daily integrated time series for the summer/wet (Fig. 8a and b) and winter/dry (Fig. 8c and d) periods. As we observed in the PSD analysis, the daily integrated time series clearly show the periodic signal with peaks at each 6-3 days. During the summer period the surface averaged $F_{\mathrm{CO} 2}$ ranged from $-8429 \mathrm{mg} \mathrm{C} \mathrm{m}^{-2}$ day $^{-1}$ to $470 \mathrm{mg} \mathrm{C} \mathrm{m}^{-2}$ day $^{-1}$ with mean value of $-1338 \mathrm{mg} \mathrm{C} \mathrm{m}^{-2}$ day $^{-1}$ (standard deviation (SD) $\pm 1335 \mathrm{mg} \mathrm{C} \mathrm{m}^{-2}$ day $^{-1}$ ). Positive values of $F_{\mathrm{CO} 2}$ (i.e., carbon absorption by reservoir) were observed just in the beginning of summer period and can be associated to the frequent algae blooms which occur during this period of year. During the winter/dry period the surface averaged $F_{\mathrm{CO} 2}$ ranged from $-3790 \mathrm{mg} \mathrm{C} \mathrm{m}^{-2}$ day $^{-1}$ to $-105 \mathrm{mg} \mathrm{C} \mathrm{m}^{-2}$ day $^{-1}$ with mean value of $-1395 \mathrm{mg} \mathrm{C} \mathrm{m}^{-2}$ day $^{-1}$ ( $\mathrm{SD} \pm 925 \mathrm{mg} \mathrm{C} \mathrm{m}^{-2}$ day $^{-1}$ ). The mean values of surface averaged $F_{\mathrm{CO} 2}$ were quite similar in both seasons and no significant difference was observed between the values $(t=0.34$, $d f=160, p>0.01$ ). However, during the summer/wet period the daily

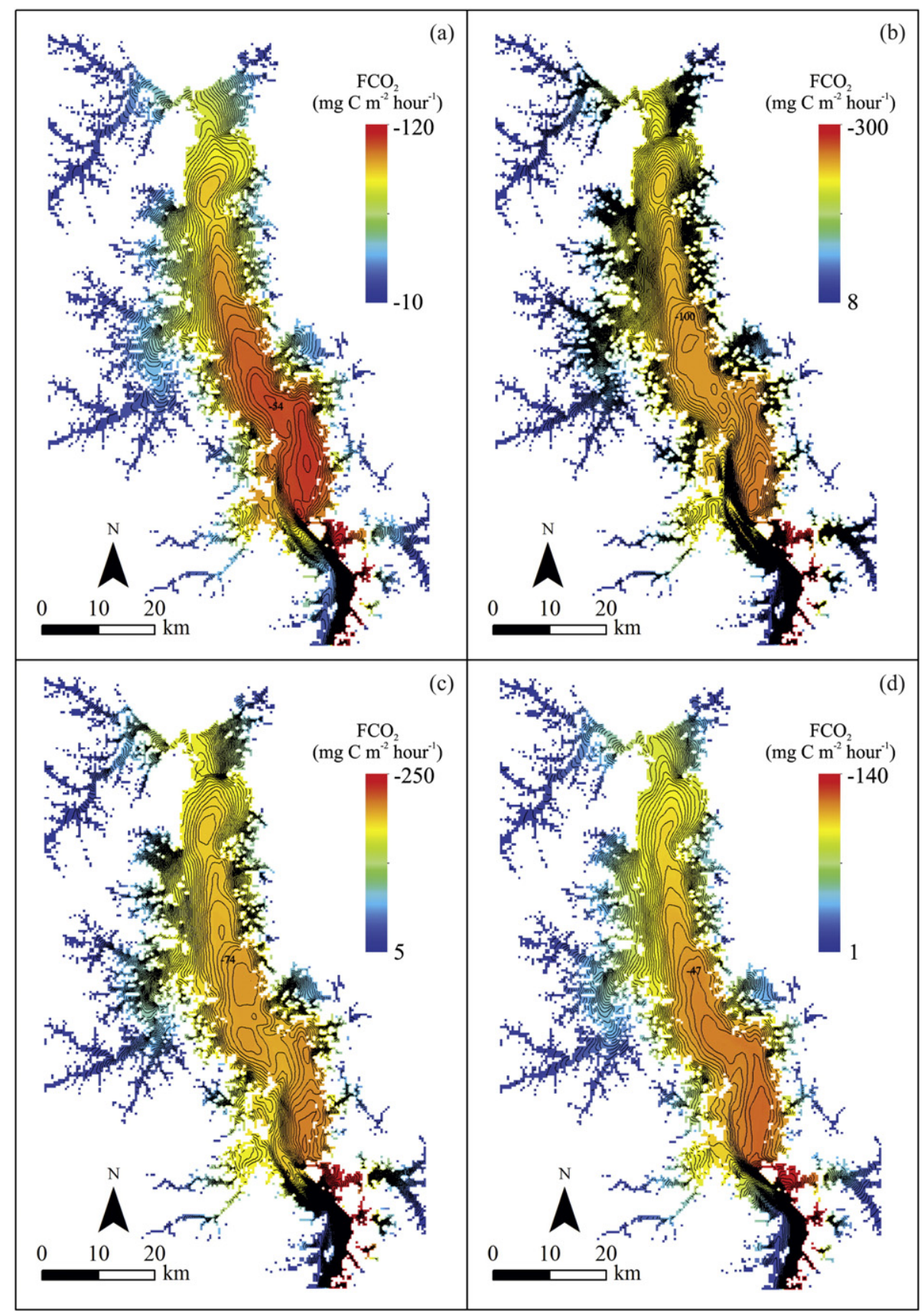

Fig. 10. Mean spatial variability of $F_{\mathrm{CO} 2}\left(\mathrm{mg} \mathrm{C} \mathrm{m}^{-2} \mathrm{~h}^{-1}\right)$ during the summer/wet period: (a) 00:00 LT, (b) 06:00 LT, (c) 12:00 LT and (d) 18:00. Isolines are at 0.5 mg C $\mathrm{m}^{-2} \mathrm{~h}^{-1}$ interval. 
integrated values of $F_{\mathrm{CO} 2}$ showed more variability than during the winter period; the variation coefficient ( $\mathrm{VC}=\mathrm{SD} /$ mean) for summer/wet time series was $100 \%$ while for winter/dry was $66 \%$.

By grouping the daily integrated $F_{\mathrm{CO} 2}$ using the nomenclature established by Duchemin et al. (1995) (i.e., regular and above-average emissions) we see that during the summer/wet season regular emissions (i.e., less than half of mean value) occurs around $28 \%$ of time while above average emissions (i.e., twice the mean) occurs just $6 \%$ of the time. For the winter/dry season, regular emissions were observed around $27 \%$ of the time and above-average emissions were observed around $12 \%$ of the time.

At diel scale (Fig. 9) $F_{\mathrm{CO} 2}$ presented a quite variable pattern in both seasons analyzed. During the summer (Fig. 9a) the $F_{\mathrm{CO} 2}$ ranged, on average, from $-101 \mathrm{mg} \mathrm{C} \mathrm{m}^{-2} \mathrm{~h}^{-1}$ to $-24 \mathrm{mg} \mathrm{C} \mathrm{m}^{-2} \mathrm{~h}^{-1}$ along the day with mean value of $-57 \mathrm{mg} \mathrm{C} \mathrm{m}^{-2} \mathrm{~h}^{-1}\left(\mathrm{SD} \pm 24 \mathrm{mg} \mathrm{C} \mathrm{m}^{-2} \mathrm{~h}^{-1}\right)$. For this season, high $\mathrm{F}_{\mathrm{CO} 2}$ values (in absolute value) were typically observed between the end of evening and night periods (from 21:00 h LT to 04:00 h LT) while low values were observed during the afternoon (from 13:00 h LT to $18: 00 \mathrm{~h} \mathrm{LT}$ ). For the winter period (Fig. $9 \mathrm{~b}$ ) the $F_{\mathrm{CO} 2}$ ranged, on average, from $-105 \mathrm{mg} \mathrm{C} \mathrm{m}^{-2} \mathrm{~h}^{-1}$ to $-30 \mathrm{mg} \mathrm{C} \mathrm{m}^{-2} \mathrm{~h}^{-1}$ along the day with mean value of $-58 \mathrm{mg} \mathrm{C} \mathrm{m}^{-2} \mathrm{~h}^{-1}\left(\mathrm{SD} \pm 28 \mathrm{mg} \mathrm{C} \mathrm{m}^{-2} \mathrm{~h}^{-1}\right)$. During this season high $\mathrm{F}_{\mathrm{CO} 2}$ values were typically observed between the night and morning periods (from 04:00 h LT to 12:00 h LT) while low values were observed between afternoon (from 14:00 h LT to 18:00 h LT). For both seasons analyzed the $\mathrm{F}_{\mathrm{CO} 2}$ showed to be more variable in the hours of day in which the $\mathrm{CO}_{2}$ fluxes were low; during the summer days the $F_{\mathrm{CO} 2}$ showed a VC of around $180 \%$ during the afternoon while during the winter days the $F_{\mathrm{CO} 2}$ showed a VC of around $150 \%$ during the afternoon.

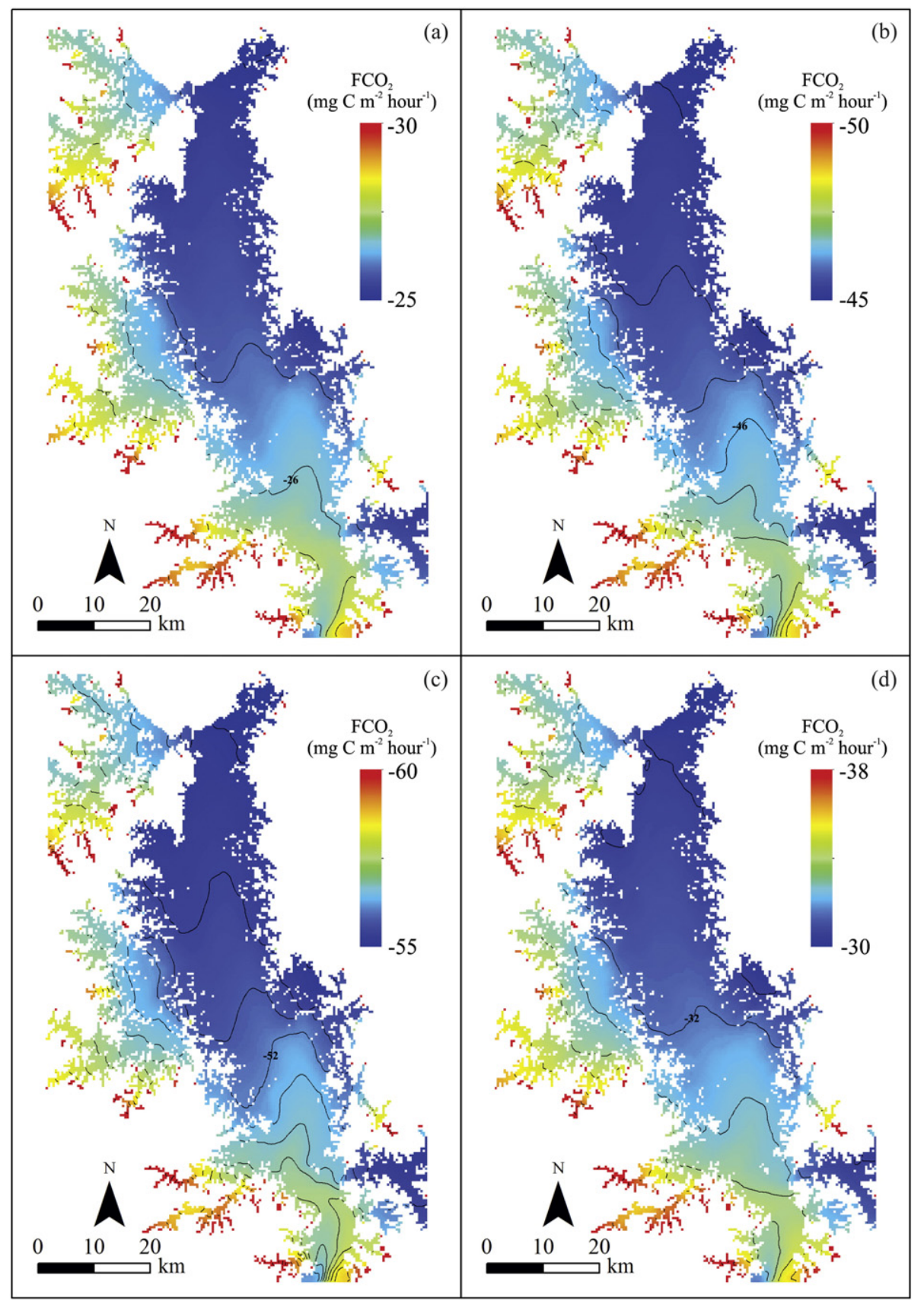

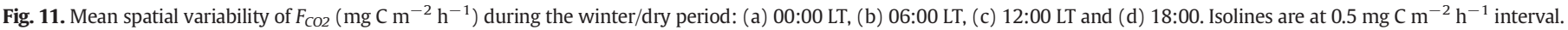


Table 4

Summary of environmental variables selected to the correlation analysis.

\begin{tabular}{|c|c|c|c|c|c|c|c|c|c|c|c|c|c|c|c|c|c|c|c|}
\hline & $F_{\mathrm{CO} 2}$ & [Chl-a] & [DIC] & $T_{w}$ & $R T$ & $k_{\mathrm{CO} 2}$ & E & $H$ & $Q_{L W}$ & $p_{\mathrm{CO} 2}$ & $P_{a t m}$ & SW & $T_{a}$ & $u_{10}$ & $R_{h}$ & $w^{*}$ & $F q$ & $u_{w}{ }^{*}$ & $h$ \\
\hline \multicolumn{20}{|c|}{ Summer/wet period } \\
\hline Mean & -1338.2 & 5.2 & 4.1 & 29.9 & 21.8 & 2.1 & -99.9 & -14.6 & -19.4 & 1139.0 & 998.7 & 193.1 & 26.9 & 2.5 & 78.2 & $3.5 \times 10-3$ & $1.7 \times 10-7$ & $3.5 \times 10-3$ & 1.3 \\
\hline Maximum & -8429.3 & 11.3 & 4.5 & 31.1 & 30.5 & 5.6 & -161.7 & -31.6 & -49.3 & 2785.0 & 1001.2 & 315.8 & 28.6 & 3.8 & 83.6 & $4.7 \times 10-3$ & $4.0 \times 10-7$ & $5.2 \times 10-3$ & 3.5 \\
\hline Minimum & 469.6 & 1.2 & 3.8 & 28.8 & 3.3 & 0.4 & -37.7 & 4.8 & 5.7 & 17.1 & 996.7 & 51.7 & 25.4 & 1.0 & 72.7 & $2.4 \times 10-3$ & $3.3 \times 10-8$ & $1.5 \times 10-3$ & 0.7 \\
\hline $\begin{array}{l}\text { Standard } \\
\text { deviation }\end{array}$ & 1334.6 & 2.9 & 0.2 & 0.7 & 6.8 & 0.9 & 25.8 & 4.7 & 8.4 & 699.4 & 1.0 & 56.8 & 0.7 & 0.6 & 2.5 & $4.4 \times 10-4$ & $6.7 \times 10-8$ & $7.5 \times 10-4$ & 0.4 \\
\hline \multicolumn{20}{|c|}{ Winter/dry period } \\
\hline Mean & -1395.3 & 1.6 & 5.8 & 30.1 & 40.0 & 2.0 & -152.8 & -17.1 & -52.2 & 1937.5 & 999.5 & 213.3 & 27.6 & 2.5 & 71.5 & $5.1 \times 10-3$ & $3.5 \times 10-7$ & $3.8 \times 10-3$ & 4.8 \\
\hline Maximum & -3789.7 & 5.0 & 6.0 & 31.1 & 72.3 & 4.3 & -206.0 & -31.1 & -78.8 & 2845.0 & 1002.4 & 299.6 & 28.8 & 4.1 & 78.1 & $8.6 \times 10-3$ & $1.0 \times 10-6$ & $6.2 \times 10-3$ & 17.6 \\
\hline Minimum & -105.4 & 0.8 & 5.5 & 29.2 & 2.5 & 0.5 & -95.5 & 8.2 & 22.5 & 920.0 & 997.1 & 109.0 & 25.9 & 1.1 & 62.3 & $3.3 \times 10-3$ & $8.9 \times 10-8$ & $1.9 \times 10-3$ & 1.1 \\
\hline $\begin{array}{l}\text { Standard } \\
\text { Deviation }\end{array}$ & 925.3 & 1.0 & 0.2 & 0.5 & 20.5 & 0.8 & 24.7 & 5.0 & 14.2 & 508.8 & 0.9 & 42.0 & 0.6 & 0.7 & 3.1 & $1.2 \times 10-3$ & $1.9 \times 10-7$ & $9.3 \times 10-4$ & 2.9 \\
\hline
\end{tabular}

\subsection{Spatial variability of $\mathrm{CO}_{2}$ flux}

To assess the spatial dynamics of $F_{\mathrm{CO} 2}$ along the day and in the different seasons we calculated the mean spatial distribution of $F_{\mathrm{CO} 2}$ at 00:00 h LT, 06:00 h LT, 12:00 h LT and 18:00 h LT for each period analyzed (Figs. 10 and 11). During the summer/wet period (Fig. 10) the $F_{\mathrm{CO} 2}$ showed a quite regular behavior along the day with the high values (in absolute value) observed at the transition zone and main body of reservoir and the low values observed at region near the dam and littoral zone; the highest value (in absolute value) were observed in the beginning of morning at transition zone where the $\mathrm{F}_{\mathrm{CO} 2}$ reached values around $-300 \mathrm{mg} \mathrm{C} \mathrm{m}^{-2} \mathrm{~h}^{-1}$ (Fig. 10b). A strong and persistent $\mathrm{F}_{\mathrm{CO} 2}$ gradient was observed between the center of main body and littoral zone along all day with an intensification of the gradient during the night until the early morning (Fig. 10a and b). The highest spatial heterogeneity was observed in the beginning of morning (Fig. 10b) with $F_{\mathrm{CO} 2}$ reaching average values of $-300 \mathrm{mg} \mathrm{C} \mathrm{m}^{-2} \mathrm{~h}^{-1}$ (transition zone), $-110 \mathrm{mg} \mathrm{C} \mathrm{m}^{-2} \mathrm{~h}^{-1}$ (main body), $-96 \mathrm{mg} \mathrm{C} \mathrm{m}^{-2} \mathrm{~h}^{-1}$ (dam zone) and $-50 \mathrm{mg} \mathrm{C} \mathrm{m}^{-2} \mathrm{~h}^{-1}$ (littoral zone). Few areas with positive $\mathrm{F}_{\mathrm{CO} 2}$ values (i.e., $\mathrm{CO}_{2}$ absorption by reservoir) where observed at littoral zone during the day time in summer period (Fig. 10b, c, and d).

As observed during the summer/wet period, the $\mathrm{F}_{\mathrm{CO} 2}$ also showed a regular behavior along the day during the winter/dry season, however, with significantly smaller magnitude and range of variation (Fig. 11). Furthermore, in opposite to the summer/wet spatial pattern, the high $F_{\mathrm{CO} 2}$ values (in absolute value) were observed at littoral zone during the winter/dry season, reaching values around $-60 \mathrm{mg} \mathrm{C} \mathrm{m}^{-2} \mathrm{~h}^{-1}$ in the noon time (Fig. 11c). The THR showed a more homogeneous $F_{\mathrm{CO} 2}$ when compared to the summer/wet spatial pattern; for winter/dry season the $F_{\mathrm{CO} 2}$ gradient between transition zone and dam region is more pronounced than the gradient between the pelagic and littoral zones. These gradients, typically, increase during the night and morning (Fig. 11a and b), reaching its maximum at the noon time (Fig. 9c) and decreasing during the afternoon and evening (Fig. 11d). For the winter/dry season the highest spatial heterogeneity was observed in the noon time (Fig. 11c) with an average $F_{\mathrm{CO} 2}$ around $-54 \mathrm{mg} \mathrm{C} \mathrm{m}^{-2} \mathrm{~h}^{-1}$ (littoral zone), $\quad-54 \mathrm{mg} \quad \mathrm{C} \mathrm{m}^{-2} \mathrm{~h}^{-1}$ (transition zone), $-51 \mathrm{mg} \mathrm{C} \mathrm{m}^{-2} \mathrm{~h}^{-1}$ (main body) and $-50 \mathrm{mg} \mathrm{C} \mathrm{m}^{-2} \mathrm{~h}^{-1}$ (dam zone).

\subsection{Environmental drivers of $\mathrm{CO}_{2}$ flux}

This section presents the results of correlation analysis conducted among the $F_{\mathrm{CO} 2}$ and environmental variables conducted to identify key meteorological forcing and physical processes governing the $\mathrm{CO}_{2}$ emissions in THR. Table 4 shows the summary of $\mathrm{F}_{\mathrm{CO} 2}$ and 18 environmental variables used in this analysis. Regarding the correlation analysis for the summer/wet period, the correlation coefficient $(r)$ ranged between -0.26 and 0.59 (Table 5 ). The high positive correlation coefficients with $\mathrm{CO}_{2}$ flux were observed for the following variables: $k_{\mathrm{CO} 2}, E, H$, $p_{\mathrm{CO} 2}, T_{w}, S W$. Only the $R_{h}$ showed a significant negative correlation with the $\mathrm{CO}_{2}$ flux. The other variables showed a weak correlation with the $F_{\mathrm{CO} 2}$ (i.e., $-0.2<r<0.2$ ).

For the winter/dry period (Table 6 ) the correlation coefficient among the $F_{\mathrm{CO} 2}$ and the 18 environmental variables ranged between -0.26 and 0.52 . The high positive correlation with the $\mathrm{CO}_{2}$ flux were observed for the following variables: $F q, w^{*}, u_{w}{ }^{*}, u_{10}, k_{\mathrm{CO} 2}, E$, h. and $H$. On the other hand

Table 5

Correlation matrix between $F_{\mathrm{CO} 2}$ and the pre-selected environmental variables for the summer/wet period.

\begin{tabular}{|c|c|c|c|c|c|c|c|c|c|c|c|c|c|c|c|c|c|c|c|}
\hline & $F_{\mathrm{CO} 2}$ & {$\left[\right.$ Chl- $a_{]}$} & {$[D I C]$} & $T_{w}$ & $R T$ & $k_{\mathrm{CO} 2}$ & $E$ & $H$ & $Q_{L W}$ & $p_{\mathrm{CO} 2}$ & $P_{a t m}$ & $S W$ & $T_{a}$ & $u_{10}$ & $R_{h}$ & $w^{*}$ & $F q$ & $u_{w}^{*}$ & $h$ \\
\hline$F_{\mathrm{CO} 2}$ & 1.00 & & & & & & & & & & & & & & & & & & \\
\hline [Chl- $a]$ & -0.08 & 1.00 & & & & & & & & & & & & & & & & & \\
\hline$[D I C]$ & -0.02 & 0.44 & 1.00 & & & & & & & & & & & & & & & & \\
\hline$T_{w}$ & 0.36 & -0.39 & -0.41 & 1.00 & & & & & & & & & & & & & & & \\
\hline$R T$ & -0.18 & 0.09 & 0.18 & 0.02 & 1.00 & & & & & & & & & & & & & & \\
\hline$k_{\mathrm{CO} 2}$ & 0.59 & -0.17 & -0.04 & -0.10 & -0.07 & 1.00 & & & & & & & & & & & & & \\
\hline$E$ & 0.52 & -0.30 & -0.57 & -0.50 & 0.33 & 0.59 & 1.00 & & & & & & & & & & & & \\
\hline$H$ & 0.51 & -0.33 & -0.46 & -0.42 & 0.18 & 0.52 & 0.83 & 1.00 & & & & & & & & & & & \\
\hline$Q_{L W}$ & 0.18 & -0.26 & -0.27 & 0.29 & 0.09 & -0.02 & 0.31 & 0.44 & 1.00 & & & & & & & & & & \\
\hline$p_{\mathrm{CO} 2}$ & 0.41 & -0.37 & 0.18 & 0.73 & 0.38 & 0.12 & 0.69 & 0.61 & 0.38 & 1.00 & & & & & & & & & \\
\hline$P_{a t m}$ & -0.15 & -0.02 & 0.37 & -0.34 & -0.28 & -0.06 & -0.37 & -0.20 & -0.14 & -0.44 & 1.00 & & & & & & & & \\
\hline SW & 0.28 & -0.02 & -0.16 & 0.25 & 0.09 & 0.12 & 0.36 & 0.42 & 0.51 & 0.32 & -0.33 & 1.00 & & & & & & & \\
\hline$T_{a}$ & 0.04 & -0.09 & -0.05 & 0.23 & 0.03 & 0.00 & -0.13 & -0.04 & 0.19 & 0.08 & -0.30 & 0.49 & 1.00 & & & & & & \\
\hline$u_{10}$ & -0.04 & -0.01 & -0.09 & 0.15 & 0.01 & 0.82 & 0.04 & 0.12 & -0.15 & 0.03 & -0.10 & -0.08 & 0.05 & 1.00 & & & & & \\
\hline$R_{h}$ & -0.26 & -0.04 & 0.09 & -0.24 & -0.11 & -0.09 & -0.28 & -0.17 & -0.37 & -0.28 & 0.35 & -0.77 & -0.74 & 0.08 & 1.00 & & & & \\
\hline$w^{*}$ & 0.13 & 0.12 & 0.00 & 0.07 & -0.06 & -0.05 & -0.05 & -0.11 & -0.18 & -0.03 & 0.08 & -0.34 & -0.34 & 0.56 & 0.34 & 1.00 & & & \\
\hline $\mathrm{Fq}$ & 0.09 & 0.18 & 0.04 & 0.19 & -0.07 & -0.06 & -0.09 & -0.11 & -0.14 & 0.03 & -0.15 & -0.02 & -0.04 & 0.71 & 0.01 & 0.59 & 1.00 & & \\
\hline$u_{w}{ }^{*}$ & -0.01 & -0.01 & -0.13 & 0.18 & 0.04 & -0.08 & 0.01 & -0.09 & -0.12 & 0.07 & -0.13 & -0.02 & 0.07 & 0.99 & 0.05 & 0.57 & 0.72 & 1.00 & \\
\hline$h$ & 0.10 & 0.32 & 0.38 & -0.29 & -0.17 & -0.09 & -0.32 & -0.44 & -0.25 & -0.46 & 0.23 & -0.44 & -0.12 & 0.24 & 0.32 & 0.51 & 0.26 & 0.22 & 1.00 \\
\hline
\end{tabular}


Table 6

Correlation matrix between $F_{\mathrm{CO} 2}$ and the pre-selected environmental variables for the winter/dry period.

\begin{tabular}{|c|c|c|c|c|c|c|c|c|c|c|c|c|c|c|c|c|c|c|c|}
\hline & $F_{\mathrm{CO} 2}$ & [Chl-a] & {$[D I C]$} & $T_{w}$ & $R T$ & $k_{\mathrm{CO} 2}$ & $E$ & $H$ & $Q_{L W}$ & $p_{\mathrm{CO} 2}$ & $P_{a t m}$ & SW & $T_{a}$ & $u 10$ & $R_{h}$ & $w^{*}$ & $F q$ & $u_{w}^{*}$ & $h$ \\
\hline$F_{\mathrm{CO} 2}$ & 1.00 & & & & & & & & & & & & & & & & & & \\
\hline [Chl-a] & -0.04 & 1.00 & & & & & & & & & & & & & & & & & \\
\hline$[D I C]$ & -0.04 & 0.55 & 1.00 & & & & & & & & & & & & & & & & \\
\hline$T_{w}$ & 0.25 & 0.54 & 0.45 & 1.00 & & & & & & & & & & & & & & & \\
\hline$R T$ & 0.07 & -0.82 & -0.91 & -0.57 & 1.00 & & & & & & & & & & & & & & \\
\hline$k_{\mathrm{CO} 2}$ & 0.47 & -0.37 & -0.49 & -0.60 & 0.47 & 1.00 & & & & & & & & & & & & & \\
\hline$E$ & 0.47 & -0.14 & -0.26 & -0.27 & 0.18 & 0.74 & 1.00 & & & & & & & & & & & & \\
\hline$H$ & 0.36 & 0.07 & 0.20 & -0.11 & -0.21 & 0.38 & 0.55 & 1.00 & & & & & & & & & & & \\
\hline$Q_{L W}$ & -0.12 & 0.19 & 0.31 & 0.44 & -0.29 & -0.38 & -0.31 & -0.23 & 1.00 & & & & & & & & & & \\
\hline$p_{\mathrm{CO} 2}$ & 0.04 & -0.15 & 0.85 & 0.30 & -0.61 & -0.42 & -0.33 & 0.09 & 0.29 & 1.00 & & & & & & & & & \\
\hline$P_{a t m}$ & 0.03 & 0.11 & 0.35 & -0.04 & -0.27 & -0.05 & -0.07 & 0.07 & 0.09 & 0.27 & 1.00 & & & & & & & & \\
\hline$S W$ & -0.26 & 0.02 & -0.07 & 0.48 & 0.03 & -0.35 & -0.12 & -0.37 & 0.30 & -0.04 & -0.17 & 1.00 & & & & & & & \\
\hline$T_{a}$ & -0.21 & 0.01 & -0.32 & 0.29 & 0.22 & -0.15 & -0.20 & -0.82 & 0.18 & -0.32 & -0.20 & 0.46 & 1.00 & & & & & & \\
\hline$u_{10}$ & 0.47 & -0.37 & -0.52 & -0.64 & 0.49 & 0.94 & 0.84 & 0.37 & -0.43 & -0.50 & -0.11 & -0.32 & -0.12 & 1.00 & & & & & \\
\hline$R_{h}$ & 0.19 & -0.03 & 0.13 & -0.40 & -0.07 & 0.32 & -0.13 & 0.66 & -0.22 & 0.14 & 0.09 & -0.58 & -0.78 & 0.28 & 1.00 & & & & \\
\hline$w^{*}$ & 0.51 & -0.29 & -0.13 & -0.66 & 0.25 & 0.60 & 0.46 & 0.37 & -0.36 & -0.09 & 0.05 & -0.52 & -0.36 & 0.64 & 0.34 & 1.00 & & & \\
\hline$F q$ & 0.52 & -0.34 & -0.25 & -0.63 & 0.34 & 0.73 & 0.57 & 0.38 & -0.39 & -0.19 & 0.00 & -0.35 & -0.27 & 0.74 & 0.28 & 0.90 & 1.00 & & \\
\hline$u_{w}^{*}$ & 0.48 & -0.36 & -0.51 & -0.64 & 0.48 & 0.95 & 0.84 & 0.40 & -0.43 & -0.49 & -0.10 & -0.34 & -0.15 & 1.00 & 0.30 & 0.65 & 0.76 & 1.00 & \\
\hline$h$ & 0.38 & -0.28 & -0.02 & -0.52 & 0.19 & 0.39 & 0.23 & 0.26 & -0.23 & 0.04 & 0.06 & -0.35 & -0.30 & 0.40 & 0.30 & 0.85 & 0.83 & 0.41 & 1.00 \\
\hline
\end{tabular}

$S W, T_{w}$ and $T_{a}$ showed low to moderate negative correlation with $F_{\mathrm{CO} 2}$. The other variables showed weak or no correlation with $\mathrm{F}_{\mathrm{CO} 2}$.

Among the variables that can directly explain the variation of $F_{\mathrm{CO} 2}$ flux in the THR, we highlighted the $k_{\mathrm{CO} 2}$. The $k_{\mathrm{CO} 2}$, in turn, can be explained by the surface wind speed and stability of the water column. In this case, the wind speed was the most correlated variable with the $k_{\mathrm{CO} 2}$ in both period $(r>0.80)$. Regarding the stability of the water column, calculated as a function of water temperature, $k_{\mathrm{CO} 2}$ and $\mathrm{T}_{\mathrm{w}}$ were significantly correlated only during the winter period $(r=-0.60)$, indicating that the thermal structure of the column water does not influence significantly the $\mathrm{CO}_{2}$ emissions during the summer period. This was expected, considering the mixed water column observed throughout the summer/wet (i.e., near the neutral stability) and stratified during the winter/dry (i.e., stable water column) (see Fig. 5).

\subsection{Global emission estimates}

The cumulative emission of diffusive $\mathrm{CO}_{2}$ along 2013 estimated using the simulated time series of $\mathrm{F}_{\mathrm{CO} 2}$ and daily values of surface area is shown in Fig. 12. The global estimate resulted in a total of $1.1 \mathrm{Tg}$ year $^{-1}$ emitted along 2013 year. As comparison to our estimate, we plotted the following estimates, based on literature data: (1) fix emission rate $\left(-2950 \mathrm{mg} \mathrm{C} \mathrm{m}{ }^{-2}\right.$ day $^{-1}$ and surface area $\left(2430 \mathrm{~km}^{2}\right)$ (Fearnside (1995)); (2) fix emission rate $\left(-2950 \mathrm{mg} \mathrm{C} \mathrm{m}^{-2}\right.$ day $^{-1}$, Fearnside (1995)) and variable surface area computed in this study; (3) fix emission rate $\left(-2311 \mathrm{mg} \mathrm{C} \mathrm{m}^{-2} \mathrm{day}^{-1}\right)$ and surface area $\left(2430 \mathrm{~km}^{2}\right.$ ) (Santos et al. (2006)); (4) fix emission rate $\left(-2311 \mathrm{mg} \mathrm{C} \mathrm{m}^{-2}\right.$ day $^{-1}$, Santos et al. (2006)) and variable surface area computed in this study; (5) fix emission rate $\left(-870 \mathrm{mg} \mathrm{C} \mathrm{m}^{-2-}\right.$ day $^{-1}$, Brazil/MME (214)) and surface area $\left(2430 \mathrm{~km}^{2}\right)$; and (6) fix emission rate $\left(-870 \mathrm{mg} \mathrm{C} \mathrm{m}^{-2}\right.$ day $^{-1}$, Brazil/MME (2014)) and variable surface area computed in this study. The global estimates were

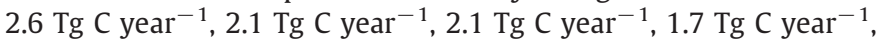
$0.8 \mathrm{Tg} C_{\text {year }}{ }^{-1}$ and $0.6 \mathrm{Tg} C$ year $^{-1}$, respectively. As we can observe by comparing the estimates (1) with (2), (3) with (4) and (5) with (6), just the inclusion of a variable surface area contributed to reduce the estimates around $18 \%$.

Comparing the results obtained in this study (1.1 $\mathrm{Tg} \mathrm{C}$ year ${ }^{-1}$, including the $F_{\mathrm{CO} 2}$ and surface area dynamics) to the estimates available in the literature, we observed that our estimates was around 57\% lower than the one calculated using Fearnside' data (2.6 $\left.\mathrm{Tg} \mathrm{C}_{\mathrm{C}} \mathrm{year}^{-1}\right), 46 \%$ lower than the one reported by Santos et al. (2006) ( 2.1 $\left.\mathrm{Tg} \mathrm{C}_{\mathrm{C}} \mathrm{ear}^{-1}\right)$ ) and 27\% higher than the one reported by Brazil/MME (2014) $\left(0.8 \mathrm{Tg}^{\mathrm{C}}\right.$ year $\left.^{-1}\right)$.

\section{Discussion and main conclusions}

\subsection{Comparison with previous studies in Tucuruí reservoir}

During the last two decades Tucuruí dam and its reservoir was the focus of a warm discussion in the literature (Rosa and Schaeffer, 1995; Fearnside, 1995; Fearnside, 2002; Rosa et al., 2006) regarding its total

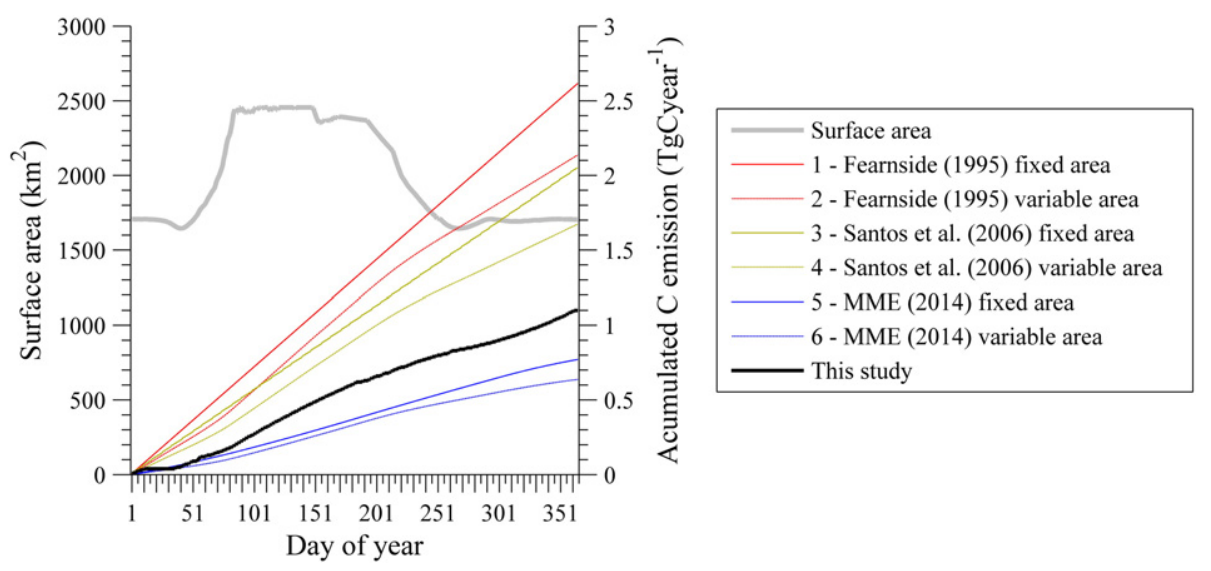

Fig. 12. Global estimates of diffusive $\mathrm{CO}_{2}$ emission $\left(\mathrm{Tg}_{\mathrm{C}}\right.$ year ${ }^{-1}$ ) from $\mathrm{THR}$ and comparison with previous published estimates. 
Table 7

Comparison with previous studies conducted at Tucuruí reservoir. Negative values indicate $\mathrm{CO}_{2}$ evasion from reservoir.

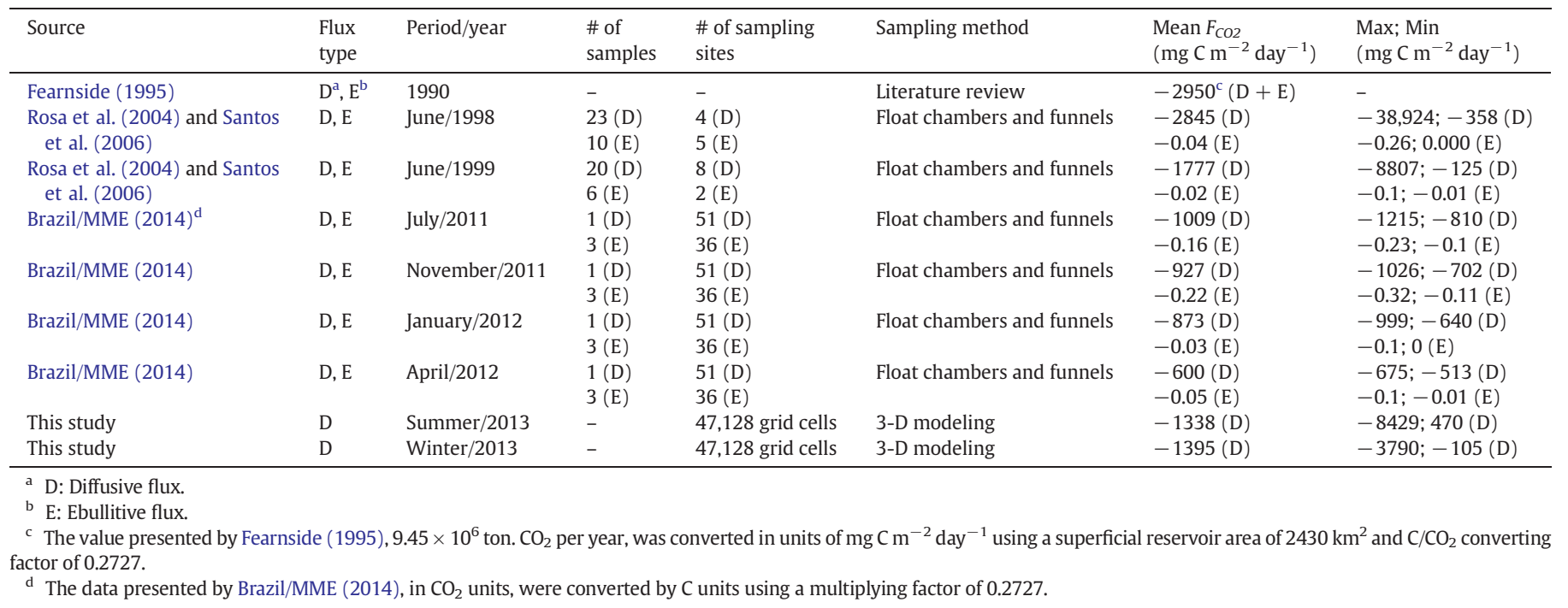

C emission and its possible contribution to climate changes. To better clarify this issue, the THR was subject of several scientific projects along this period. Table 7 presents a summary of studies which investigated the diffusive $\mathrm{CO}_{2}$ emission from THR. By comparing our results to those reported by Fearnside (1995); Rosa et al. (2004); Santos et al. (2006) and Brazil/MME (2014) we can observed a clear decrease trend in the $F_{\mathrm{CO} 2}$ with the reservoir age. A regression analysis between $F_{\mathrm{CO} 2}$ and reservoir age showed a significant logarithm relation $\left(R^{2}=\right.$ 0.7) (Fig. 13). It is consistent with the findings of Barros et al. (2011), which compiled information from more than 80 hydroelectric reservoirs around the world and also found a logarithm relation between reservoir age and $\mathrm{CO}_{2}$ emissions.

The difference between $F_{\mathrm{CO} 2}$ estimated by Fearnside (1995) (reference year 1990) and by our study (reference year 2013) is around $1600 \mathrm{mg} \mathrm{C} \mathrm{m}^{-2}$ day $^{-1}$, which indicates a reduction of $54 \%$ between 1990 and 2013. The decay rate was higher between 1990 and 1999, when the $F_{\mathrm{CO} 2}$ decreased around $130 \mathrm{mg} \mathrm{C} \mathrm{m}^{-2}$ day ${ }^{-1}$ per year; between 1999 and 2013 the $F_{\mathrm{CO} 2}$ decreased around $30 \mathrm{mg} \mathrm{C} \mathrm{m}^{-2}$ day $^{-1}$ per year. Much of the decay observed in the $F_{\mathrm{CO} 2}$ along the years can be explained by the consumption of fixed carbon sources, such as the trees killed by flooding the reservoir and stocks of carbon in the soil (Fearnside and Pueyo, 2012).

\subsection{Implications for global carbon assessment of Amazonian reservoirs}

In this study we showed that the inclusion of spatial and temporal dynamics of $F_{\mathrm{CO} 2}$, as well as, the inclusion of surface area dynamic

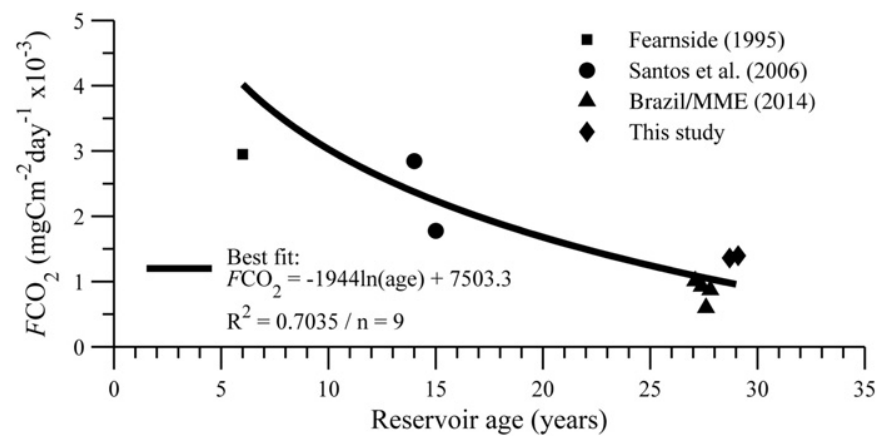

Fig. 13. Relation between THR age (years) and $F_{\mathrm{CO} 2}\left(\mathrm{mg} \mathrm{C} \mathrm{m}^{-2}\right.$ day $\left.^{-1}\right)$. along the year has a great impact on the estimates of diffusive $\mathrm{CO}_{2}$ emission from THR. As THR is one of the main reservoirs located within Amazon region, accounting for nearly $30 \%$ of total of the carbon emitted as $\mathrm{CO}_{2}$ by Amazonian reservoirs, we highlight that our results will impact significantly the estimates of carbon emission from all Amazonian hydroelectric reservoirs.

A recent global estimative of carbon emission from hydroelectric reservoirs indicates that the reservoirs located at Amazonian region emit a total of $9 \mathrm{Tg} \mathrm{C}$ year ${ }^{-1}$, being $8 \mathrm{TgC}$ emitted as $\mathrm{CO}_{2}$ and $1 \mathrm{Tg} \mathrm{C}$ as $\mathrm{CH}_{4}$ (Barros et al., 2011). This estimate was based on literature review and considered studies conducted at 6 different reservoirs: 5 located within the International Amazon (Balbina, Curua-Uná, Petit Saut, Samuel and Tucuruí) and 1 located out of International Amazon boundary (Gatun Lake). In this study, the quantification of the total carbon emission was done by multiplying the average areal flux of each gas $\left(-1518 \mathrm{mg} \mathrm{C} \mathrm{m}^{-2}\right.$ day $^{-1}$ for $\mathrm{CO}_{2}$ and $-186 \mathrm{mg} \mathrm{C} \mathrm{m}^{-2}$ day $^{-1}$ for $\mathrm{CH}_{4}$, see Table $\mathrm{S} 2$ in the supplementary information from Barros et al. (2011)) by the area covered by the reservoirs (considered to be equal $2 \times 10^{4} \mathrm{~km}^{2}$, ICOLD (2003)).

Taking into account the results obtained in our study, we argue that the global carbon emission reported by Barros et al. (2011) are excessively overestimated due to improper handling of the data in their calculations and for not accounting the dynamics of $F_{\mathrm{CO} 2}$ and reservoir surface area changes along the year. First, Barros et al. (2011) included repeated information to compute the average areal flux; Tucuruí and Samuel reservoirs reviews, for example, included two different studies which published the same dataset collected between 1998 and 1999 (Rosa et al., 2004; Santos et al., 2006). Second, the authors not considered the $\mathrm{CO}_{2}$ flux data available for Balbina reservoir $\left(76 \mathrm{mmol} \mathrm{CO}_{2} \mathrm{~m}^{-2-}\right.$ day $^{-1}$ ) (Guérin et al., 2006). The authors included considered reservoirs of different ages to compute the mean areal $F_{\mathrm{CO} 2}$, ignoring the natural decay of $\mathrm{CO}_{2}$ emissions. Finally, they included the Gatun Lake (located outside the Amazonian boundary) in their estimative (see Tables S1 and S2 in the supplementary information from Barros et al. (2011)).

Based on the above, we re-calculated the global carbon emission from Amazonian hydroelectric reservoirs using the mean value of $F_{\mathrm{CO} 2}$ simulated for THR in this study $\left(-1366 \mathrm{~g} \mathrm{C}^{2}\right.$ day $\left.^{-1}\right)$, which is a more recent value compared to that reported by Santos et al. (2006). We also excluded the repeated values of the areal $\mathrm{CO}_{2}$ and $\mathrm{CH}_{4}$ flux for Samuel reservoir and Gatun Lake data, and included the value of areal $\mathrm{CO}_{2}$ flux of Balbina reservoir, provided by Guérin et al. (2006). All $F_{\mathrm{CO} 2}$ data was updated to 2013 using the relation observed between 
$F_{\mathrm{CO} 2}$ and age in THR in this study (see Fig. 13). As result we found that the average areal flux of the Amazonian hydroelectric reservoirs is around $-1400 \mathrm{mg} \mathrm{C} \mathrm{m}^{2}$ day $^{-1}$ for $\mathrm{CO}_{2}$ and $-166 \mathrm{mg} \mathrm{C} \mathrm{m}^{2}$ day $^{-1}$ for $\mathrm{CH}_{4}$. Taking into account the total area covered by Amazonian hydroelectric reservoirs, about $2 \times 10^{4} \mathrm{~km}^{2}$, we estimate that the carbon emission from Amazonian hydroelectric reservoirs is near to $8.6 \mathrm{Tg} \mathrm{C}_{\mathrm{Cear}}{ }^{-1}$, being $7.7 \mathrm{Tg} C$ year $^{-1}$ as $\mathrm{CO}_{2}$ and $0.9 \mathrm{Tg} \mathrm{C}_{\text {year }}{ }^{-1}$ as $\mathrm{CH}_{4}$ (not considering the surface area variation along the year). This value is $5 \%$ lower than the value reported by Barros et al. (2011). However, if we consider the variation of surface area along the year this estimative can be even smaller. As we showed in the results section, the inclusion of variable surface area along the year can impact the total emission by around $18 \%$. Assuming that the Amazonian hydroelectric reservoirs shows a similar operational behavior to that observed in THR we speculate that the global carbon emission from Amazonian hydroelectric reservoirs could be about $7 \mathrm{Tg}^{\mathrm{C}}$ year $^{-1}$, a value $22 \%$ lower than the estimated by Barros et al. (2011).

As showed in this study, the inclusion of spatial and temporal variability of $F_{\mathrm{CO} 2}$, as well as the dynamics of surface area along the year brings new insights about the carbon emissions and the role of Amazonian hydroelectric reservoirs in the terrestrial carbon cycle. We consider that the methodological approach used in this study of an the integrated use of 3-D ecological model, telemetric in situ data and remote sensing observations can fill important gaps associated with spatial and temporal under sampling sometimes observed in conventional data collection used to study carbon emissions from large water bodies as those in the Amazon. Our approach reveals a significant difference $(\sim 35 \%)$ in relation to those published in the literature (e.g., Santos et al. (2006) and Barros et al. (2011)). This significant difference should not be neglected in the future carbon inventories of Amazonian reservoirs, since the carbon emission is a key factor when comparing the environmental impacts of different sources of electricity generation and can influence decision makers in the selection of more appropriate source of electricity and, in case of hydroelectricity, the geographical position of the reservoirs.

\section{Acknowledgements}

The authors wish to thank the Remote Sensing Division (DSR) and the Hydrosphere Research Group of the National Institute for Space Research (INPE) for providing the infrastructure to conduct this study. The authors also thank Dr. Julio Pablo Reyes Fernandez for his contributions and insights about the modeling approach. The first author is grateful to the Brazilian Council of Technological and Scientific Development (CNPq) for the doctorate-level scholarship (under grant 161233/ 2013-9). C. A. S. A. wishes to thank the CNPq (grant 300177/2015-1) for the PCI scholarship. The field campaigns were supported by the Eletronorte (grant 4500075234) and the Brazilian Electricity Regulatory Agency (ANEEL, grant 8000003629). The SIMA platform and thermistor chains were funded by the Brazilian Electricity Regulatory Agency (ANEEL, grant 8000003629). The authors are grateful to the Centre for Water Research (CWR), University of Western Australia (UWA), for providing the ELCOM-CAEDYM model for this study and to the National Institute of Science and Technology for Climate Change (INCT for Climate Change) for funding the ELCOM-CAEDYM model license.

\section{Appendix A. Supplementary data}

Supplementary data to this article can be found online at http://dx. doi.org/10.1016/j.scitotenv.2016.02.001.

\section{References}

Aberg, J., Bergstrom, A.K., Algesten, G., Soderback, K., Jansson, M., 2004. A comparison of the carbon balances of a natural lake (L. Ortrasket) and a hydroelectric reservoir
(L. Skinnmuddselet) in Northern Sweden. Water Res. 38, 531-538. http://dx.doi. org/10.1016/j.watres.2003.10.035.

Abril, G., Guerin, F., Richard, S., Relmas, R., 2005. Carbon dioxide and methane emissions and the carbon budget of a 10-year old tropical reservoir (Petit Saut, French Guiana). Glob. Biogeochem. Cycles 19, GB4007. http://dx.doi.org/10.1029/2005GB002457.

Ackerman, S.A., Strabala, K.I., Menzel, W.P., Frey, R.A., Moeller, C.C., Gumley, L.E., 1998. Discriminating clear-sky from clouds with MODIS. J. Geophys. Res. Atmos. 103, 32141-32173. http://dx.doi.org/10.1029/1998JD200032.

Alcântara, E., Curtarelli, M., Ogashawara, I., Stech, J., Souza, A., 2013. A system for environmental monitoring of hydroelectric reservoirs in Brazil. Ambiente Água 8, 6-17. http://dx.doi.org/10.4136/ambi-agua.1088.

Barros, N., Cole, J.J., Tranvik, L.J., Prairie, Y.T., Bastviken, D., Huszar, V.L.M., Del Giorgio, P., Roland, F., 2011. Carbon emission from hydroelectric reservoirs linked to reservoir age and latitude. Nat. Geosci. 4, 593-596. http://dx.doi.org/ 10.1038/ngeo1211.

Bergier, I., Novo, E.M.L.M., Ramos, F.M., Mazzi, E.A., Rasera, M.F.F.L., 2011. Carbon dioxide and methane fluxes in the littoral zone of a tropical savanna reservoir (Corumbá, Brazil). Oecol. Aust. 15, 666-681. http://dx.doi.org/10.4257/oeco.2011.1503.17.

Brazil, Ministry of Mines and Energy (Brazil/MME), 2014. Emissões de gases de efeito estufa em reservatórios de centrais hidrelétricas. MME/ANEEL (in Portuguese).

Bruce, L.C., Hamilton, D.P., Imberger, J., Gal, G., Gophen, M., Zohary, T., Hambright, K.D., 2006. A numerical simulation of the role of zooplankton in $\mathrm{C}, \mathrm{N}$ and $\mathrm{P}$ cycling in Lake Kinneret, Israel. Ecol. Model. 193, 412-436. http://dx.doi.org/10.1016/j. ecolmodel.2005.09.008.

Casulli, V., Cheng, R.T., 1992. Semi-implicit finite difference methods for threedimensional shallow water flow. Int. J. Numer. Methods Fluids 15, 629-648. http:// dx.doi.org/10.1002/fld.1650150602.

Curtarelli, M.P., Alcântara, E.H., Rennó, C.D., Stech, J.L., 2004b. Physical changes within a large tropical hydroelectric reservoir induced by wintertime cold front activity. Hydrol. Earth Syst. Sci. 18, 3079-3093. http://dx.doi.org/10.5194/hess-183079-2014.

Curtarelli, M.P., Ogashawara, I., Araújo, C.A.S., Alcântara, E., Lorenzzetti, J.A., Stech, J.L., 2014a. Influence of summertime mesoscale convective systems on the heat balance and surface mixed layer dynamics of a large Amazonian hydroelectric reservoir. J. Geophys. Res. Oceans 119, 8472-8498. http://dx.doi.org/10.1002/2014JC010288.

Curtarelli, M.P. Ogashawara, I Allcântara, E.H., Stech, J.L, 2015a. Coupling remote sensing bio-optical and three-dimensional hydrodynamic modeling to study the phytoplankton dynamics in a tropical hydroelectric reservoir. Remote Sens. Environ. 157, 185-198. http://dx.doi.org/10.1016/j.rse.2014.06.013.

Curtarelli, M.P., Leão, J.A.D., Ogashawara, I., Lorenzzetti, J.A., Stech, J., 2015b. Assessment of spatial interpolation methods to map the bathymetry of an Amazonian hydroelectric reservoir to aid in decision making for water management. ISPRS Int. J. Geo-Inf. 4, 220-235. http://dx.doi.org/10.3390/ijgi4010220.

De Lima, I.B.T., de Moraes Novo, E.M.L., Ballester, M.V.R., Ometto, J.P., 1998. Methane production, transport and emission in Amazon hydroelectric plants. INTERNATIONAL GEOSCIENCE AND REMOTE SENSING SYMPOSIUM, (IGARSS'98)., 1998, Seattle, USA. Proceedings http://dx.doi.org/10.1109/IGARSS.1998.702268.

Deus, R., Brito, D., Kenov, I.A., Lima, M., Costa, V., Medeiros, A., Neves, R., Alves, C.N., 2013. Three-dimensional model for analysis of spatial and temporal patterns of phytoplankton in Tucuruí reservoir, Pará, Brazil. Ecol. Model. 253, 28-43. http://dx.doi. org/10.1016/j.ecolmodel.2012.10.013.

Duchemin, E., Lucotte, M., Canuel, R., Chamberland, A., 1995. Production of the greenhouse gases $\mathrm{CH}_{4}$ and $\mathrm{CO}_{2}$ by hydroelectric reservoirs of the boreal region. Glob. Biogeochem. Cycles 9, 529-540. http://dx.doi.org/10.1029/95GB02202.

Eugster, W., Kling, G., Jonas, T., McFadden, J.P., Wüest, A., MacIntyre, S., Chapin III, F.S., 2003. $\mathrm{CO}_{2}$ exchange between air and water in an Arctic Alaskan and midlatitude Swiss lake: importance of convective mixing. J. Geophys. Res. Atmos. 108, 1-7. http://dx.doi.org/10.1029/2002JD002653.

Fearnside, P.M., 1995. Hydroelectric dams in Brazilian Amazonia as sources of greenhouse gases. Environ. Conserv. 22, 7-19.

Fearnside, P.M., 2002. Greenhouse gas emissions from a hydroelectric reservoir (Brazil's Tucuruí dam) and the energy policy implications. Water Air Soil Pollut. 133, 69-96. http://dx.doi.org/10.1023/A:1012971715668.

Fearnside, P.M., Pueyo, S., 2012. Greenhouse-gas emissions from tropical dams. Nat. Clim. Chang. 2, 382-384. http://dx.doi.org/10.1038/nclimate1540.

Friedl, M.A., Sulla-Menashe, D., Tan, B., Schneider, A., Ramankutty, N., Sibley, A., Huang, X., 2010. MODIS collection 5 global land cover: algorithm refinements and characterization of new datasets. Remote Sens. Environ. 114, 168-182. http://dx.doi.org/10.1016/ j.rse.2009.08.016

Gal, G., Hipsey, M.R., Parparov, A., Wagner, U., Makler, V., Zohary, T., 2009. Implementation of ecological modeling as an effective management and investigation tool: Lake Kinneret as a case study. Ecol. Model. 220, 1697-1718. http://dx.doi.org/10. 1016/j.ecolmodel.2009.04.010.

Galy-Lacaux, C., Delmas, R., Jambert, C., Dumestre, J.F., Labroue, L., Richard, S., Gosse, P., 1997. Gaseous emissions and oxygen consumption in hydroelectric dams: a case study in French Guyana. Glob. Biogeochem. Cycles 11, 471-483. http://dx.doi.org/ 10.1029/97GB01625.

Galy-Lacaux, C., Delmas, R., Kouadio, G., Richard, S., Gosse, P., 1999. Long-term greenhouse gas emissions from hydroelectric reservoirs in tropical forest regions. Glob. Biogeochem. Cycles 13, 503-517. http://dx.doi.org/10.1029/ 1998 GB900015.

Guérin, F., Abril, G., Richard, S., Burban, B., Reynouard, C., Seyler, P., Delmas, R., 2006. Methane and carbon dioxide emissions from tropical reservoirs: significance of downstream rivers. Geophys. Res. Lett. 33, 1-6. http://dx.doi.org/10.1029/2006GL027929.

Hicks, B.B., 1975. A procedure for the formulation of bulk transfer coefficients over water. Bound.-Layer Meteorol. 8, 515-524. http://dx.doi.org/10.1007/BF02153568. 
Hipsey, M.R., Antenucci, J.P., Hamilton, D., 2014. Computational aquatic ecosystem dynamics model: CAEDYM v3. V3.2 science manual. University of Western Australia/ Centre for Water Research.

Hodges, B.R., Imberger, J., Saggio, A., Winters, K.B., 2000. Modeling basin-scale internal waves in a stratified lake. Limnol. Oceanogr. 45, 1603-1620. http://dx.doi.org/10. 4319/lo.2000.45.7.1603.

Horel, J.D., Hahmann, A.N., Geisler, J.E., 1989. An investigation of the annual cycle of convective activity over tropical Americas. J. Clim. 2, 1388-1403. http://dx.doi.org/10. 1175/1520-0442(1989)002\%3C1388:AIOTAC\%3E2.0.CO;2.

Huffman, G.J., Alder, R.F., Bolvin, D.T., et al., 2007. The TRMM multisatellite precipitation analysis (TMPA): quasi-global, multiyear, combined-sensor precipitation estimates at fine scales. J. Hydrometeorol. 8, 38-55. http://dx.doi.org/10.1175/JHM560.1.

Huttunen, J.T., Vaisanen, T.S., Hellsten, S.K., et al., 2002. Fluxes of $\mathrm{CH}_{4}, \mathrm{CO}_{2}$, and $\mathrm{N}_{2} \mathrm{O}$ in hydroelectric reservoirs Lokka and Porttipahta in the northern boreal zone in Finland. Glob. Biogeochem. Cycles 16, 1-17. http://dx.doi.org/10.1029/2000GB001316.

Imberger, J., Patterson, J.C., 1989. Physical limnology. Adv. Appl. Mech. 27, 303-475.

International Commission of Large Dams (ICOLD), 2003. World register of large dams 2003. ICOLD.

Keller, M., Stallard, R.F., 1994. Methane emission by bubbling from Gatun Lake, Panama. J. Geophys. Res. Atmos. 99, 8307-8319. http://dx.doi.org/10.1029/92JD02170.

Kemenes, A., Forsberg, B.R., Melack, J.M., 2007. Methane release below a tropical hydroelectric dam. Geophys. Res. Lett. 34 (L12809), 1-5. http://dx.doi.org/10.1029/ 2007 GL029479.

Leon, L.F., Lam, D.C., Schertzer, W.M., Swayne, D.A., Imberger, J., et al., Sep. 2008. Lake and climate models: interactions in small and large lakes. St. Petersburg, Russia. Presented at "Workshop on parameterization of lakes in NWP and climate modelling 18-20.

Leonard, B.P., 1991. The ULTIMATE conservative difference scheme applied to unsteady one-dimensional advection. Comput. Methods Appl. Mech. Eng. 88, 17-74. http:// dx.doi.org/10.1016/0045-7825(91)90232-U.

Lima, I.B.T., 2005. Biogeochemical distinction of methane releases from two Amazon hydroreservoirs. Chemosphere 59, 1697-1702. http://dx.doi.org/10.1016/j. chemosphere.2004.12.011.

Lobato, T.C., Hauser-Davis, R.A., Oliveira, T.F., Maciel, M.C., Tavares, M.R.M., Silveira, A.M. Saraiva, A.C.F., 2014. Categorization of the trophic status of a hydroelectric power plant reservoir in the Brazilian Amazon by statistical analyses and fuzzy approaches. Sci. Total Environ. 506-507, 613-620. http://dx.doi.org/10.1016/j.scitotenv.2014.11. 032.

Marti, C., et al., Oct. 2007. Coupled physical-biogeochemical modelling of GHG emissions from freshwater reservoirs. Foz do Iguaçu, Brazil. Presented at "II workshop on greenhouse status of freshwater reservoirs 4-5.

Menshutkin, V.V., Rukhovets, L.A.L.A., Filatov, N.N., 2014. Ecosystem modeling of Freshwater Lakes (review): 2. Models of Freshwater Lake's ecosystem. Hydrophys. Process. 41, 32-45. http://dx.doi.org/10.1134/S0097807814010084.

Missaghi, S., Hondzo, M., 2010. Evaluation and application of a three-dimensional water quality model in a shallow lake with complex morphometry. Ecol. Model. 221, 1512-1525. http://dx.doi.org/10.1016/j.ecolmodel.2010.02.006.

Mooij, W.M., Trolle, D., Jeppesen, E., Arhonditsis, G., Belolipetskym, P.V., Chitamwebwa, D.B.R., et al., 2010. Challenges and opportunities for integrating lake ecosystem modelling approaches. Aquatic Ecology 44, 633-667. http://dx.doi.org/10.1007/ s10452-010-9339-3.

Ometto, J.P., Cimbleris, A.C.P., Santos, M.A., et al., 2013. Carbon emission as a function of energy generation in hydroelectric reservoirs in Brazilian dry tropical biome. Energy Policy 58, 109-116. http://dx.doi.org/10.1016/j.enpol.2013.02.041.

Pacheco, F.S., Assireu, A.T., Roland, F., 2011. Derivadores rastreados por satélites aplicados a ambientes aquáticos continentais: caso do reservatório de Manso. In: Alcântara, E.H., Stech, J.L., Novo, E.M.L.M. (Eds.), Novas tecnologias para o monitoramento e estudo de reservatórios hidrelétricos e grandes Lagos. Parêntese, pp. 193-218 (in Portuguese).

Pacheco, F.S., Soares, M.C.S., Assireu, A.T., et al., 2015. The effects of river inflow and retention time on the spatial heterogeneity of chlorophyll and water-air $\mathrm{CO}_{2}$ fluxes in a tropical hydropower reservoir. Biogeosciences 12, 147-162. http://dx.doi.org/10. 5194/bg-12-147-2015.

Peel, M.C., Finlayson, B.L., McMahon, T.A., 2007. Updated world map of the Köppen-Geiger climate classification. Hydrol. Earth Syst. Sci. 11, 1633-1644. http://dx.doi.org/10. 5194/hess-11-1633-2007.

Polsenaere, P., Deborde, J., Detandt, G., Vidal, L.O., Pérez, M.A.P., Marieu, V., Abril, G., 2013. Thermal enhancement of gas transfer velocity of $\mathrm{CO}_{2}$ in an Amazon floodplain lake revealed by eddy covariance measurements. Geophys. Res. Lett. 40, 1734-1740 (http://dx.doi.prg/ 0.1002/grl.50291).

Robson, B.J., Hamilton, D.P., 2004. Three-dimensional modelling of a microcystis bloom event in the Swan River estuary, Western Australia. Ecol. Model. 174, 203-222. http://dx.doi.org/10.1016/j.ecolmodel.2004.01.006.
Roland, F., Vidal, L.O., Pacheco, F.S., Barros, N.O., Assireu, A., Ometto, J., Cimbleris, A.C.P. Cole, J.J., 2010. Variability of carbon dioxide flux from tropical (Cerrado) hydroelectric reservoirs. Aquat. Sci. 3, 283-293. http://dx.doi.org/10.1007/s00027-010-0140-0.

Romero, J.R., Antenucci, J.P., Imberger, J., 2004. One- and three- dimensional biogeochemical simulations of two differing reservoirs. Ecol. Model. 174, 143-160. http://dx.doi. org/10.1016/j.ecolmodel.2004.01.005.

Rosa, L.P., Schaeffer, 1995. Global warming potentials: the case of emissions from dams Energ Policy 23, 149-158. http://dx.doi.org/10.1016/0301-4215(95)91418-C.

Rosa, L.P., Santos, M.A., Matvienko, B., Santos, E.O., Sikar, E., 2004. Greenhouse gas emissions from hydroelectric reservoirs in tropical regions. Clim. Chang. 66, 9-21. http://dx.doi.org/10.1023/B:CLIM.0000043158.52222.ee.

Rosa, L.P., Dos Santos, M.A., Matvienko, B., Sikar, E., Dos Santos, E.O., 2006. Scientific errors in the Fearnside comments on greenhouse gas emissions (GHG) from hydroelectric dams and response to his political claiming. Clim. Chang. 75, 91-102 (2006 http:// dx.doi.org/10.1007/s10584-005-9046-6).

Rudd, J.W.M., Harris, R., Kelly, C.A., Hecky, R.E., 1993. Are hydroelectric reservoirs significant sources of greenhouse gases. Ambio 22, 246-248.

Santos, M.A., Rosa, L.P., Sikar, B., Sikar, E., Santos, E.O., 2006. Gross greenhouse gas fluxes from hydro-power reservoir compared to thermo-power plants. Energy Policy 34, 481-488. http://dx.doi.org/10.1016/j.enpol.2004.06.015.

Santoso, A.B., Hamilton, D.P., Schipper, L.A., Hendy, C., Ozkundakci, D., Ostrovsky, I., Hipsey, M.R., et al., 2015. Modelling CO2 and CH4 dynamics in a small, eutrophic, monomictic lake. JOINT ASSEMBLY AGU-GAC-MAC-CGU., 2015, Montreal, Canada. Proceedings.

Silva, C., Marti, C.L., Imberger, J., 2014. Physical and biological controls of algal blooms in the Río de la Plata. Environ. Fluid Mech. 14, 1199-1228. http://dx.doi.org/10.1007/ s10652-014-9342-7.

Slater, P.N., 1980. Remote Sensing: Optics and Optical Systems. Addison-Wesley.

Soumis, N., Duchemin, E., Canuel, R., Lucotte, M., 2004. Greenhouse gas emissions from reservoirs of the Western United States. Glob. Biogeochem. Cycles 18, GB3022. http://dx.doi.org/10.1029/2003GB002197.

Spillman, C.M., Imberger, J., Hamilton, D.P., Hipsey, M.R., Romero, J.R., 2007. Modelling the effects of Po River discharge, internal nutrient cycling and hydrodynamics on biogeochemistry of the Northern Adriatic Sea. J. Mar. Syst. 68, 167-200. http://dx.doi.org/10 1016/j.jmarsys.2006.11.006.

St Louis, V.L., Kelly, C.A., Duchemin, É., Rudd, J.W.M., Rosenberg, D.M., et al., 2000. Reservoir surfaces as sources of greenhouse gases to the atmosphere: a global estimate. Bioscience 50, 766-775 (http://dx.doi.org/10.1641/0006-3568(2000)050[0766: RSASOG]2.0.C.).

Stech, J.L., Lima, I.B.T., Novo, E.M.L.M., et al., 2006. Telemetric monitoring system for meteorological and limnological data acquisition. Verh. Int. Ver. Limnol. 29, 1747-1750.

Tavares, M.D.R.M., 2011. Estrutura da comunidade microfitoplanctônica da área de influência da UHE de Tucuruí-Pará (Master thesis) Federal Univ. of Pará (in Portuguese)

Therrien, J., Tremblay, A., Jacques, R.B., 2005. CO2 Emissions from Semi-arid Reservoirs and Natural Aquatic Ecosystems. In: Tremblay, A et al (Eds.). Greenhouse Gas Emissions: fluxes and processes, hydroelectric reservoirs and natural environments. Springer, Berlin, p. 732.

Tranvik, L.J., Downing, J.A., Cotner, J.B., et al., 2009. Lakes and reservoirs as regulators of carbon cycling and climate. Limnol. Oceanogr. 54, 2298-2314. http://dx.doi.org/10. 4319/lo.2009.54.6_part_2.2298.

Tremblay, A., Varfalvy, C. Roehm, Garneau, M. (Eds.), 2005. Greenhouse Gas Emissions Fluxes and Processes Hydroelectric Reservoirs and Natural Environments. Springer.

Trolle, D., Hamilton, D.P., Pilditch, C.A., Duggan, I.C., Jeppesen, E., 2011. Predicting the effects of climate change on trophic status of three morphologically varying lakes: Implications for lake restoration and management. Environ. Model Softw. 26, 354-370. http://dx.doi.org/10.1016/j.envsoft.2010.08.009.

Tundisi, J.G., Santos, M.A., Menezes, C.F.S., 2005. Tucuruí Reservoir: Experience and Lessons Learned Brief. International Waters Learning Exchange \& Resource Network.

Wallace, B.B., Bailey, M.C., Hamilton, D.P., 2000. Simulation of vertical position of buoyancy regulating Microcystis aeruginosa in a shallow eutrophic lake. Aquat. Sci. 62, 320-333. http://dx.doi.org/10.1007/PL00001338.

Wanninkhof, R., 1992. Relationship between wind speed and gas exchange over the ocean. J. Geophys. Res. Oceans 97, 7373-7382. http://dx.doi.org/10.1029/92JC00188.

Weiss, R.F., 1974. Carbon dioxide in water and seawater: the solubility of a non-ideal gas Mar. Chem. 2, 203-215. http://dx.doi.org/10.1016/0304-4203(74)90015-2.

Wüest, A., Lorke, A., 2003. Small-scale hydrodynamics. Annu. Rev. Fluid Mech. 35 373-412. http://dx.doi.org/10.1146/annurev.fluid.35.101101.161220.

Xiao, S., Wang, Y., Liu, D., Yang, Z., Lei, D., Zhang, C., 2013. Diel and seasonal variation of methane and carbon dioxide fluxes at site guojiaba, the three gorges reservoir. J. Environ. Sci. 25, 2065-5071. http://dx.doi.org/10.1016/S1001-0742(12)60269-1. 